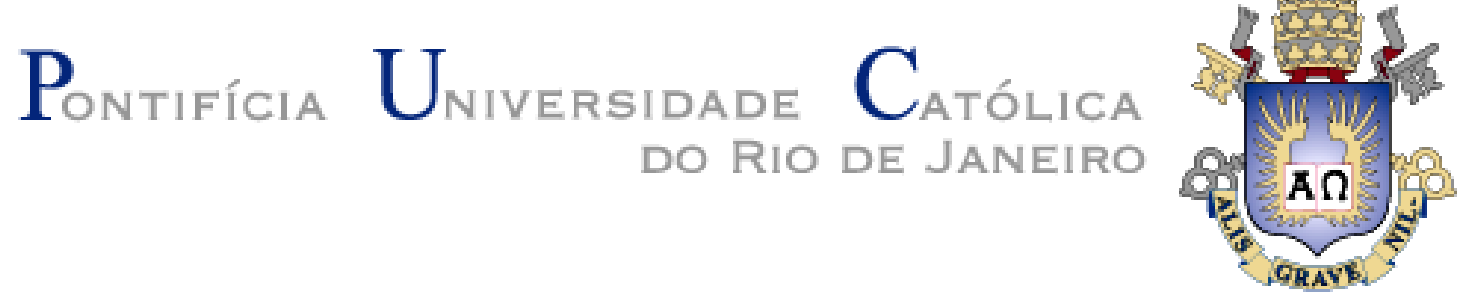

Rony Natale Pereira

\title{
A transgressão como saída psíquica vital
}

\section{Dissertação de Mestrado}

Dissertação apresentada como requisito parcial para a obtenção do grau de Mestre pelo Programa de Pós-Graduação em Psicologia Clínica do Departamento de Psicologia da PUC-Rio.

Orientadora: Profa. Monah Winograd 
Rony Natale Pereira

\section{A transgressão como saída psíquica vital}

Dissertação apresentada como requisito parcial para obtenção do grau de Mestre pelo Programa de PósGraduação em Psicologia (Psicologia Clínica) da PUCRio. Aprovada pela Comissão Examinadora abaixo assinada.

Profa. Monah Winograd

Orientadora

Departamento de Psicologia - PUC-Rio

Profa. Maria Isabel de Andrade Fortes

Departamento de Psicologia - PUC-Rio

Prof. Ney Klier Padilha Netto

Departamento de Psicologia - PUC-Rio

Prof. Leif Ericksson Nunes Grünewald Universidade Federal da Grande Dourados - UFGD

Profa. Monah Winograd

Coordenadora Setorial de Pós-Graduação

e Pesquisa do Centro de Teologia e Ciências Humanas - PUC-Rio

Rio de Janeiro, 28 de janeiro de 2019. 
Todos os direitos reservados. É proibida a reprodução total ou parcial do trabalho sem autorização da universidade, do autor e do orientador.

\section{Rony Natale Pereira}

Graduou-se em psicologia na UFES (Universidade Federal do Espírito Santo). Especialização em Psicanálise e desafios contemporâneos Faculdade Pitágoras em 2012.

Ficha Catalográfica

Pereira, Rony Natale

A transgressão como saída psíquica vital / Rony Natale Pereira; orientadora: Monah Winograd. - 2019.

$96 \mathrm{f} . ; 30 \mathrm{~cm}$

Dissertação (mestrado)-Pontifícia Universidade Católica do Rio de Janeiro, Departamento de Psicologia, 2019.

Inclui bibliografia

1. Psicologia - Teses. 2. Transgressão. 3. Pulsão de morte. 4. Pulsão anarquista. 5. Trabalho de civilização. 6. Trabalho de cultura. I. Winograd, Monah. II. Pontifícia Universidade Católica do Rio de Janeiro. Departamento de Psicologia. III. Título.

CDD: 150 


\section{Agradecimentos}

À PUC-Rio, à CAPES e ao CNPq pelos apoios disponibilizados;

À minha orientadora, Profa. Monah Winograd, pela aposta, confiança e precisão das palavras;

Ao Ney Klier, pela dedicação, paciência e rigor, sobretudo nos momentos de crise;

À Profa. Isabel Fortes e ao Prof. Leif Grünewald, pela disposição em compor a banca examinadora e oferecer suas contribuições ao meu trabalho;

Ao meu companheiro Leo, à família, aos amigos, por entenderem as ausências e me incentivarem a prosseguir;

Ao Grupo de Estudos em Psicanálise de Vitória, pela enorme contribuição no meu percurso de formação;

Ao Paulo, meu analista, por me comprometer com meu desejo ao mesmo tempo respeitando os necessários "desligamentos";

À Gabriela, pela agradável parceria e preciosas indicações durante o curso.

O presente trabalho foi realizado com apoio da Coordenação de Aperfeiçoamento de Pessoal de Nível Superior - Brasil (CAPES) - Código de Financiamento 001. 


\section{Resumo}

Pereira, Rony Natale; Winograd, Monah (Orientadora). A transgressão como saída psíquica vital. Rio de Janeiro, 2019, 96 p. Dissertação de Mestrado - Departamento de Psicologia, Pontifícia Universidade Católica do Rio de Janeiro.

Esta dissertação tem por objetivo investigar o aspecto transgressivo que caracteriza o pensamento da psicanalista francesa Nathalie Zaltzman ao revisitar a metapsicologia freudiana. Com a acepção de "ultrapassar", "violar", "não cumprir", a transgressão revela-se uma ação psíquica vital para o sujeito, sobretudo quando esse se encontra em perigo de vida devido a circunstâncias opressoras e asfixiantes. Iniciamos nossa investigação por meio da articulação teórica do viés anarquista da pulsão de morte, manifestação em forma de luta e resistência contra forças que diminuem ou anulam a existência de um ser humano. A partir dessa perspectiva, percorremos proposições acerca da clínica. Destacamos a importância dada à ação de desligamento da pulsão de morte e a urgência da escuta, durante o tratamento, de suas manifestações. Expandindo a discussão com a abordagem do processo civilizatório, demonstramos como o trabalho de cultura poderia ser considerado o seu viés transgressor. Por meio desse, poder-se-ia lidar de maneira mais lúcida com a dimensão maléfica do humano, evitada a qualquer custo pela perspectiva civilizatória. Afirma-se a necessidade de fomentar vias que façam frente a posturas censoras e moralizantes. Essas impediriam o mal, dimensão inelutável e inerente à condição humana, de ocupar lugar nas representações psíquicas conscientes de cada indivíduo e no patrimônio simbólico da humanidade. Uma vez impedido, só lhe restaria abrir caminhos violentos de satisfação, reascendendo a barbárie.

\section{Palavras-chave}

Transgressão; pulsão de morte; pulsão anarquista; clínica psicanalítica; trabalho de civilização; trabalho de cultura. 


\section{Abstract}

Pereira, Rony Natale; Winograd, Monah (Advisor). Transgression as a vital psychic outlet. Rio de Janeiro, 2019, 96 p. Dissertação de Mestrado Departamento de Psicologia, Pontifícia Universidade Católica do Rio de Janeiro.

The present dissertation aims to investigate the transgressive aspect which characterizes the thoughts of the French psychoanalyst Nathalie Zaltzman in review of freudian metapsychology. With the sense of "overtaking", "violating", "unaccomplishing", transgression is revealed as a vital psychic way out, specially when one's life is endangered due to oppressive and suffocating circumstances. We start our investigation with the theoretical articulation of the anarchist aspect of death drive, a manifestation characterized by the struggle and resistance against forces which dominate, diminish or nullify the human being existence. Based upon such perspective, we go along propositions about the clinic. We outline the importance given to the act of unattachment from death drive and the urgency of its listening, throughout the treatment, its manifestations. In order to take part in the discussion with the civilizing process, we demonstrate how culture work may be considered its transgressive way. By taking such approach for granted one could handle with a more lucid way in facing the maleficent dimension of the human, which is avoided by all costs in the civilizing perspective. It is argued the need to promote ways of confronting censorship and moralizing positions. Such act would prevent evil, ineluctable and insisting dimension of the human, from taking place in the conscious psychic representations of each single person and in the symbolic patrimony of humanity. Once there is an imposition, the only way left is to open violent paths of satisfaction, reigniting barbarism.

\section{Keywords}

Transgression; death drive; anarchist drive; psychoanalytical clinic; civilizing process; culture process. 


\section{Sumário}

1 Introdução $\quad 8$

$\begin{array}{ll}2 \text { A via transgressiva da pulsão de morte } & 14\end{array}$

$\begin{array}{ll}2.1 \text { O campo metapsicológico } & 16\end{array}$

$\begin{array}{ll}2.2 \text { Da pulsão sexual às pulsões de morte } & 19\end{array}$

2.3 A pulsão de morte como protesto vital 25

2.4 A pulsão de morte na vida cotidiana $\quad 30$

$2.5 \mathrm{O}$ risco de morrer na luta por viver 32

3 Pulsão de morte e a transgressividade da clínica $\quad 35$

3.1 A representação da pulsão de morte 36

$\begin{array}{ll}3.2 \text { Crítica à exclusividade do sexual } & 40\end{array}$

3.3 Um caso clínico $\quad 48$

3.4 Adoecimento e cura em psicanálise $\quad 51$

3.5 Transgredir por pertencer: o coletivo no contexto da clínica 57

4 A via transgressiva do processo civilizatório $\quad 68$

$\begin{array}{ll}\text { 4.1 Trabalho de cultura versus trabalho de civilização } & 70\end{array}$

4.2 Abordagem psicanalítica do mal $\quad 74$

$4.3 \mathrm{O}$ mal como uma constante não evolutiva $\quad 78$

4.4 O crime contra a humanidade e o intocável do mal $\quad 81$

$\begin{array}{ll}\text { 4.5 Do evitamento ao acolhimento do mal } & 84\end{array}$

4.6 Possibilidades e limites do trabalho de cultura 86

$\begin{array}{lr}5 \text { Considerações finais } & 89\end{array}$

6 Referências Bibliográficas 92 


\section{1 \\ Introdução}

Esta dissertação é o resultado de um imprevisto. Nosso objetivo inicial foi investigar o tema da pulsão de morte no pensamento da psicanalista francesa Nathalie Zaltzman. Sem conhecermos a fundo sua obra, sabíamos que essa era uma temática à qual ela se dedicava, de onde surgiu o conceito mais reverenciado por seus leitores, o de "pulsão anarquista". Passamos a esmiuçar seus ensaios, os de seus comentadores, dos autores aos quais ela se referenciava e assim o imprevisto foi tomando forma. Descobrimos que, partindo da "pulsão anarquista" todo um pensamento pode ser reconhecido girando em torno de suas apostas transgressivas. Zaltzman transgride posturas teóricas, convida o interlocutor a transgredir e aponta esse caminho como vital ao funcionamento psíquico individual e coletivo.

Foi possível, ao longo do trabalho, conferirmos à transgressão o papel de fio condutor da pesquisa, a partir do qual abordamos a metapsicologia, a clínica e a cultura, segundo o pensamento combativo da psicanalista em questão.

Inicialmente, nos dedicamos estritamente à temática mais presente em seus ensaios, a pulsão de morte. Em seu retorno ao legado freudiano, Zaltzman propôs releituras que vigorosamente defendem, revisam e ampliam em alguns aspectos a concepção freudiana desta força. Para cumprirmos tal objetivo, foi necessário também acompanharmos o percurso freudiano quanto ao desenvolvimento de tal construto. Na verdade, ao longo de toda a pesquisa nos remetemos aos ensaios de Freud, o que foi imprescindível para compreendermos as propostas da autora. Consideramos, muitas vezes, ter promovido um diálogo entre suas ideias, expondo como Zaltzman, em momento algum, se desvencilha dos fundamentos estabelecidos pelo criador da psicanálise, embora não tenha evitado criticá-lo quando julgava pertinente.

É sobretudo na abordagem clínica da pulsão de morte que veremos comparecer tais críticas. Não fazia sentido, para ela, a proposição de uma atividade psíquica essencialmente "muda", cujos efeitos não eram passíveis de intervenção pelo método analítico. Ancorada nas observações de sua prática, mas também atenta a 
situações da vida, das mais dramáticas às corriqueiras, concebe algumas reformulações da metapsicologia da pulsão de morte, sendo essa a temática que norteia quase toda sua trajetória teórica, que vai da década 1970 até o ano de 2007.

Apesar de não ser uma autora amplamente conhecida no meio acadêmico e psicanalítico, localizamos uma vasta bibliografia por ela escrita. Dentre os diversos ensaios, alguns foram reunidos em livros. "A pulsão anarquista" (ZALTZMAN, 1979/1994) é o primeiro deles, onde ela rastreia a pulsão de morte no terreno da experiência analítica e no qual encontramos uma ferrenha defesa, pautada em sua prática, da consideração pelas manifestações de Tânatos nos fenômenos da vida e no manejo da clínica pelo analista. É nesse trabalho que nasce o que consideramos a maior contribuição da autora ao legado freudiano: o conceito de pulsão anarquista, dimensão de protesto vital da pulsão de morte, o qual conferiu visibilidade à sua obra, sendo o único livro com edição em português, no Brasil, já em 1994.

Neste primeiro momento de sua trajetória, identificamos o seu empenho em iluminar as manifestações de luta em defesa da vida ou, ao menos, da sobrevivência, empreendidas pela pulsão de morte. Inspirada nos movimentos anarquistas, a autora revela haver um quinhão de Tânatos que irromperia quando a vida estivesse em risco, quando o poder do outro, muitas vezes decorrente da ação de Eros, asfixiasse e submetesse o sujeito.

Foi justamente a aproximação do ensaio inaugural que despertou em nós o interesse em rastrear o viés transgressivo que se apresenta, inicialmente, sob a insígnia da pulsão anarquista. A leitura de comentadores de seu trabalho só confirmava a suspeita de que, conforme propôs André (2011), a pulsão anarquista evocaria a própria pessoa de Zaltzman, sua conduta na vida, sua existência, e não apenas um argumento teórico. A postura combativa, de recusa a toda forma de poder, permeia a obra da autora e foi esse o aspecto central e determinante que buscamos investigar.

O verbo "transgredir" geralmente é utilizado no sentido de "violar", "não cumprir", remetendo a uma ação que vai de encontro à uma lei, uma regra estabelecida. Mas também remete a "ir além de", "atravessar" (HOUAISS, 2005). 
Quaisquer dessas acepções nos permitem indicar que a obra de Zaltzman se constitui revelando movimentos de transgressão do funcionamento psíquico e, por consequência, da clínica e da cultura. Mas a transgressão que ela propõe assume um valor positivo ao aportar a possibilidade de o pensar e o agir humanos tomarem a direção de insistência na vida frente às perspectivas da morte e da destruição.

Sempre em retorno aos textos de Freud, especialmente aqueles posteriores a 1920, a psicanalista procura encontrar saídas para os enigmas e pessimismos por ele evidenciados, notadamente frente à existência da pulsão de morte. Nesta oportunidade, outros aspectos constitutivos do sofrimento humano, abrigados pela teoria freudiana sob a alcunha de "resistência à análise" - como o horror ao feminino, a bissexualidade e a cisão do eu -, ganham lugar ao lado do constructo acima referido. Por essa razão, a autora chama a atenção dos analistas quanto às últimas revisões empreendidas pelo criador da psicanálise no que diz respeito à cura analítica. Ela convoca os leitores a perceberem preciosos acréscimos à metapsicologia que Freud propõe já encerrando seu legado.

Voltando cada vez mais suas preocupações ao mal-estar que aflige o coletivo, em seus últimos escritos, sobretudo no livro “L'Esprit du mal” (ZALTZMAN, 2007), acompanhamos a tentativa da analista em conceber uma abordagem mais lúcida da dimensão do mal. Novamente, a recusa às forças de submetimento e domínio é acionada.

Desta vez, a via encontrada foi uma apreensão específica do termo "trabalho de cultura" extraído dos ensaios freudianos nos quais é abordado o processo civilizatório ou, nas palavras de Freud, cultural. Zaltzman (2007) põe em dúvida justamente esta aproximação feita por ele (FREUD, 1930/2010, 1932/2010, 1933a/2010) entre os dois processos. Demonstra como a obra do autor remete a definições potencialmente diferentes para os termos trabalho de civilização e trabalho de cultura, sendo este último essencial para uma apreensão menos idílica da definição de humanidade, a qual deveria incluir a instância do mal.

Ao final, a pesquisa foi estruturada do seguinte modo: no primeiro capítulo, nos preocupamos inicialmente em compreender um pouco melhor o campo 
metapsicológico, alicerce para o desenvolvimento da pesquisa e da clínica em psicanálise. Após esboçarmos a estrutura constitutiva da metapsicologia, investigamos a construção do conceito de pulsão de morte por Freud (1920/2010), argumento chave para entender a revisão empreendida por Zaltzman. Isso exigiu que partíssemos das primeiras elaborações acerca da pulsão, quando, ainda em 1905, estavam atreladas predominantemente à libido, e acompanhássemos as viradas teóricas a partir da introdução do conceito de narcisismo (FREUD, 1915/2010) até o anúncio da pulsão de morte na passagem para a década seguinte.

Na sequência, introduzimos o pensamento de Zaltzman (1979/1994) com a proposição que consideramos ser, possivelmente, o ápice de sua obra: a apresentação da dimensão libertária, rebelde e anárquica da pulsão de morte, a "pulsão anarquista" - termo cunhado por ela para designar justamente a expressão combativa do controverso conceito freudiano, revelando sua visada de proteção à vida e luta contra a morte. A pulsão anarquista seria, sem dúvida, um dos aspectos mais importantes do trabalho da psicanalista, demonstrando o viés transgressivo tanto de seu pensamento quanto dos conceitos que aborda ao longo de sua produção teórica.

A partir deste primeiro encontro com sua escrita, balizamos a pesquisa no sentido de encontrar, na trajetória teórica de Zaltzman, mais indícios de suas proposições transgressivas e a importância dada por ela a tal postura para a vitalidade psíquica do humano. No percurso, foi possível compreender como a autora consolida esta via como alternativa à perspectiva predominantemente pessimista que se revela sobretudo nos últimos escritos de Freud tanto em relação à clínica quanto ao progresso humano enquanto sociedade.

Importante frisarmos, desde já, que Zaltzman nunca demonstrou qualquer sinal de ilusão frente à postura desacreditada de Freud (1930/2010, 1932/2010). Ao contrário, buscou encontrar na obra do criador da psicanálise argumentos que validassem a contribuição da disciplina psicanalítica frente ao desamparo humano, sobretudo aquele decorrente das forças da morte e da destruição que se mostravam cada vez mais indubitáveis. Sempre destacou, contudo, os limites de tal proposta, notadamente ao abordar a ideia de cura em psicanálise e a de processo civilizatório. 
Esses serão os dois temas tratados nos capítulos seguintes. No segundo capítulo, voltamos nossa atenção às proposições da psicanalista acerca da clínica, sempre a partir do relevo dado à dimensão da pulsão de morte e sua importância como operador clínico. Afirma-se o protagonismo de Tânatos no desenrolar da análise, o que não pode ser desconsiderado pelo analista, sob pena de limitar o alcance da cura ou, ainda mais grave, piorar o estado do paciente. Uma crítica contundente ao privilégio e à exclusividade concedidos à sexualidade na etiologia das diversas manifestações do sofrimento humano é apresentada, a qual ilustramos reunindo e articulando fragmentos de um caso clínico que a autora desenvolve ao longo de seu primeiro livro (ZALTZMAN, 1979/1994).

Como caminhos frente aos impasses da clínica, abordamos a convocação feita aos analistas a ampliarem o olhar acerca da obra freudiana, sobretudo quanto à consideração por seus trabalhos testamentários. Dentre eles, "Moisés e o monoteísmo" (FREUD, 1939 [1934-1938]/2018) ocupará um lugar especial nas indicações da autora, para quem, nesse ensaio, Freud teria nos deixado indicações mais otimistas, na medida do realismo e da lucidez de sua obra, quanto à experiência humana como parte do coletivo, o que reverbera em implicações positivas também para a prática psicanalítica. A dimensão coletiva da existência humana, ainda que engendre suas maiores dificuldades, se apresenta como a possibilidade de pensarmos acerca da cura em psicanálise.

No terceiro e último capítulo abordamos as ideias contidas no livro ' $L$ 'Esprit du mal" (ZALTZMAN, 2007) relacionadas à dimensão humana do mal frente ao processo civilizatório. Como uma das formas de manifestação da pulsão de morte, mas também da sexual, o mal revelaria aquilo que a civilização evita considerar como parte da constituição humana, muito embora seja o que, ao longo da história, se repete sem se fazer objeto de transformação.

Para compreender este evitamento, a autora faz uma leitura singular dos conceitos de trabalho de cultura e trabalho de civilização, os quais, segundo ela, podem ser apreendidos de modos diferentes na obra freudiana. $\mathrm{O}$ trabalho de cultura, conforme comparece na Conferência 31 (FREUD, 1933/2010), seria de ordem intrapsíquica, passagem de conteúdos do Id à consciência, resultando em 
ganho de Eu. Já o trabalho de civilização diria respeito aos ganhos que a sociedade oferece aos sujeitos, às obras que permitem a convivência social, a educação, a moral, a religião, o direito, a política, com acréscimos de conteúdos vindos do ambiente externo, mas sempre pautados na exigência da renúncia pulsional e das aspirações individuais em conflito com a convivência coletiva.

O processo de análise se alinharia ao trabalho de cultura, permitindo a mudança ao fomentar a movimentação de conteúdos entre os sistemas psíquicos, fundamento da cura em psicanálise. Já o processo civilizatório seria aliado do recalque e da neurose, ao submeter as aspirações individuais à necessidade da convivência em grupo. Ambos cumpririam um papel no pretenso progresso da humanidade, mas o ganho advindo do trabalho de cultura seria transgressivo, contribuindo por uma via singular ao avanço da comunidade humana. $\mathrm{O}$ trabalho de civilização, por outro lado, seria repressivo e os ganhos decorrentes de tal processo não ocorreriam sem fomentar o recalque, o adoecimento neurótico e a eclosão, a nível individual e coletivo, de formas violentas de satisfação pulsional. É o que abordaremos ao longo do último capítulo. 


\section{2}

\section{A via transgressiva da pulsão de morte}

Os remanejamentos na metapsicologia consolidados a partir do ensaio "Além do princípio do prazer" (FREUD, 1920/2010), com a afirmação do conceito de pulsão de morte, deflagraram certa resistência e rejeição ao novo modelo teórico proposto (FREUD, 1930/2010). De acordo com Green (1988/1990), admitir as opiniões de Freud depois da "virada de 1920", para muitos analistas, era condenarse a deixar de exercer a psicanálise frente a um inimigo tão potente ao sucesso terapêutico. Por outro lado, analistas que acolheram as mudanças propostas se lançaram à sua justificativa e desenvolvimento, mesmo décadas após a segunda teoria pulsional consolidada. Dentre eles, destacamos a francesa Nathalie Zaltzman, cujos escritos surgiram mais de meio século após concluídas as duas teorias pulsionais de Freud. A psicanalista se mostrou engajada em aprofundar a compreensão das novidades trazidas pelo autor, além de apresentar justificativas que demonstrassem o quão necessário era considerá-las para o vigor e fecundidade da clínica psicanalítica. Mais do que isso, revelou dimensões não reportadas na literatura analítica desde o surgimento do novo modelo teórico.

Zaltzman pretendeu trazer novo vigor ao conceito de pulsão de morte, tema que aparece ao longo de sua obra, iniciada na década de 1970 e encerrada na década de 2000, pouco antes de sua morte, em 2009. A autora reúne observações e reflexões acerca da atividade da pulsão de morte na vida psíquica, através das quais também revelou um viés negligenciado dessa força pulsional. Se empenhou em esclarecer como tal construto deve ser considerado ferramenta de trabalho na clínica e não apenas um obstáculo ao tratamento. Utilizou argumentos e vivências extraídas de sua prática, a partir da qual nos conduz a uma leitura potencializadora e positivadora do conceito.

Embora não poupasse críticas a alguns aspectos do modelo teórico apresentado por Freud (1920/2010), a autora se manteve alinhada às proposições originais, não pretendendo construir um modelo próprio para explicar seu ponto de vista. Ao contrário, procura, através de sua clínica, confirmar as hipóteses freudianas fundamentais, dando relevo a alguns aspectos que entendeu serem frágeis ou ausentes, podendo em alguns momentos se apoiar em teorias de outros 
autores. Na maior parte dos ensaios que exploramos, seu trabalho foi dar visibilidade a aspectos que já circundam o conceito originalmente estabelecido. Vemos sempre a tentativa de demonstrar que o avanço da psicanálise, sobretudo quanto aos efeitos de cura, estaria prejudicado sem considerar esta parte da metapsicologia.

Filha de judeus russos exilados na França, com os quais fugiu para o sul do país durante a Segunda Guerra, Zaltzman foi marcada pelo contexto do holocausto e da violência, cujas reverberações sentiu na própria pele. A autora apresenta, portanto, uma obra nitidamente marcada por sua história e os impactos desta na clínica que exerceu, sendo a pulsão de morte um conceito bastante apropriado para suas leituras de mundo. Uma linguagem rica em metáforas de guerra permeia seus escritos, notadamente “A pulsão anarquista" (ZALTZMAN, 1979/1994), publicação inaugural. Nos apresenta, por meio desse construto que dá nome ao trabalho, uma força transgressiva, combativa, que fomenta trajetórias de luta, nutre a vontade de protesto contra situações de domínio, a despeito de todos os outros modos de comparecer que remetam à desintegração e ao adoecimento. Considera se tratar de um impulso do qual certas evoluções são muito úteis à vida, mesmo quando em forma de resistência para garantir o mínimo de ligações necessárias à sobrevivência.

Neste primeiro capítulo, vamos apresentar o percurso teórico inicial de Zaltzman, cujos ensaios encerram as principais contribuições ao conceito de pulsão de morte. Sua primeira obra, a mais conhecida e única publicada no Brasil (em 1994), pode ser considerada o estandarte de seu pensamento. Embora o conceito de pulsão anarquista, único forjado pela autora, não compareça em nenhum outro ensaio posterior, a ideia que ele transmite perpassa toda a trajetória teórica e clínica da psicanalista. A novidade da proposição de Nathalie Zaltzman é apreender, no agenciamento da pulsão anarquista, uma forma de resistência vital contra ameaças que podem levar à morte. Por esta via, a pulsão de morte assume a forma de representante psíquico que sustenta a autoconservação da vida (BEETSCHEN, 2011).

Além dessa formulação mais audaciosa, acompanharemos as considerações que a autora desenvolve nos anos seguintes, sobretudo em "Une volonté de mort" 
(ZALTZMAN, 1988/2008), onde se ocupa em expor sua compreensão acerca do funcionamento mais geral da pulsão de morte. São propostas mais despreocupadas em revelar novas dimensões conceituais, mas que também explicam a possibilidade das manifestações transgressivas defendidas em seu primeiro trabalho. Percorremos afirmações e questionamentos de enunciados presentes desde Freud, que importam por colocarem em questão a necessidade de se considerar a novidade anunciada com a segunda teoria pulsional. A partir disso, a analista esmiúça sua apreensão do conceito de pulsão de morte, que ela chamou Tânatos, o que nos ajudará a acompanhar as indicações clínicas que oferece e que abordaremos no segundo capítulo da presente dissertação.

Consideramos importante, de início, apresentar, ainda que brevemente, como se estruturou a metapsicologia freudiana, e retornar aos fundamentos do conceito de pulsão de morte. São bases teóricas às quais nos remeteremos, assim como Zaltzman fez ao longo de sua obra, durante toda a pesquisa. Feito isto, passaremos à investigação mais precisa do pensamento da autora. Embora sem pretender inaugurar um novo modelo teórico, ela traz indicações bastante esclarecedoras, sobretudo por se pautar em exemplos da clínica, mas também da literatura, da antropologia e da história.

\section{1 \\ O campo metapsicológico}

Ao apresentar a metapsicologia, Freud pretendeu desenvolver a psicanálise numa teoria explicativa acabada, mas sempre aberta a novas contribuições e descobertas, de modo que os conceitos fundamentais, fixados em definições, experimentam uma constante alteração de conteúdo. É este modelo teórico não hermético que permite às novas gerações de psicanalistas e pesquisadores renovarem o saber, sobretudo ao fazê-lo dialogar com as questões contemporâneas a uma sociedade, relançando a aposta freudiana de se poder intervir no sofrimento humano.

A metapsicologia consistiu, desde o início, em uma disciplina que liga processos psíquicos a sistemas topicamente determinados, os quais possuem uma organização e um funcionamento específicos. Embora o termo metapsicologia 
tivesse sido empregado por Freud desde os primórdios de seu pensamento psicanalítico, foi em “A interpretação dos sonhos” (FREUD, 1900/1969), no famoso capítulo VII, que o fundador da psicanálise sistematizou os diversos conceitos formulados anteriormente, apresentando um modelo de aparelho psíquico que expressava a inovação com relação à concepção que se tinha do psiquismo até aquele momento (BIRMAN, 2009). Com a obra "Três ensaios sobre a teoria da sexualidade" (FREUD, 1905/2016), a teoria se organiza e os conceitos de pulsão e sexualidade são introduzidos.

Ferenczi (1922/2011), dentre os que circundavam Freud, foi um dos primeiros autores a confirmar a herança metapsicológica como estrutura teórica possível de esclarecer as diferentes interconexões dos sistemas e como elas explicam os variados modos de descarga, normais e patológicos, das excitações. Os sistemas seriam acionados por forças psíquicas derivadas de transformações das correntes pulsionais presentes no organismo, cuja distribuição varia segundo distintos modos de descarga da excitação. As pulsões seriam as forças que alcançam internamente o psiquismo e impulsionam ao trabalho a fim de realizar a descarga, sua meta (FREUD, 1905/2016).

Mas, conforme Birman (2009), antes de chegar a conceitos como pulsão, aparelho psíquico, inconsciente, Freud percebera, desde seu trabalho com as histéricas, que havia uma efetividade terapêutica da linguagem e do discurso, o que o levou a crer que o aparelho psíquico estaria fundado na linguagem. Além da linguagem, importava também a circulação das intensidades, conforme a experiência clínica com a terapêutica catártica realizada junto a Breuer havia demonstrado. O aparelho seria constituído, então, pela articulação entre representações e intensidades (BIRMAN, 2009). Seriam os efeitos da sexualidade neste duplo registro psíquico que conduziriam à divisão psíquica, evidenciando haver uma conflitualidade que originaria tal divisão.

Chegou-se, conforme Eksterman (1987), à concepção de um aparelho constituído de diversos espaços psíquicos, atravessados por forças e investimentos que colocam tais espaços em movimento, configurando diferentes relações entre eles. Temos aí o que seriam as dimensões tópica, dinâmica e econômica do funcionamento psíquico. A primeira, referida aos diferentes espaços intrapsíquicos. 
Já a segunda dimensão, a dinâmica, estaria referida ao conflito de forças. A terceira, econômica, estaria referida às intensidades. Eis a descrição metapsicológica do psiquismo, que tem como eixo o inconsciente. Discriminá-lo, conhecer suas funções, propriedades e conteúdo é a tarefa da metapsicologia.

O aspecto dinâmico dessa construção teórica permite compreendermos as relações do sistema inconsciente com a consciência, configurando relações de forças em operação que podem se associar, confluir, divergir e conflitar. São essas relações que tornam compreensíveis os fenômenos psíquicos normais e patológicos, especialmente o conflito psíquico, cujas nuances estão na origem das diversas manifestações patológicas.

A quantidade de energia disponível da pulsão definiria o aspecto econômico, logo, as relações do sistema inconsciente com a dimensão biológica, a qual seria a única fornecedora de energia para as operações mentais.

O aspecto topográfico aparece como o lugar das operações de tais forças, sendo o elemento definidor da metapsicologia, pois contém justamente o conceito de inconsciente como produtor da representação inconsciente - que, para se tornar consciente, necessita associar-se à palavra (EKSTERMAN, 1987). Por esta razão, a origem primária de toda atividade mental, é que Freud considera o inconsciente a “verdadeira realidade psíquica” (FREUD, 1900/1969, p. 651).

Segundo Assoun (1976/1978), a psicanálise, na condição de meta-psicologia, só é possível como trabalho de transformação que o psiquismo efetua de si mesmo em seu objeto. O que a tornaria possível é a tendência à objetivação imanente ao trabalho do psiquismo, que tende a materializar o conflito psíquico representandoo e o tornando manifesto, portanto acessível a uma investigação.

Zaltzman (1996) põe em relevo a intrincação inseparável de dois pontos de vista: o do avanço metapsicológico e o da cura psicanalítica. Segundo a autora, a metapsicologia freudiana avança conforme um modelo comum a todas as suas revisões. Sua evolução seria uma apropriação, em termos de novos conhecimentos, dos obstáculos sucessivos ao desenrolar da experiência clínica. As resistências ao processo e o que entrava seu poder de ação são, para a metapsicologia, reversíveis: a novidade inicia um remanejamento metapsicológico, abrindo uma nova via terapêutica. 
Freud (1940 [1938]a/2018), já em seu percurso final, descreve as resistências oriundas da pulsão de morte como obstáculos frente aos quais os meios disponíveis pela técnica psicanalítica eram insuficientes para combater. Teria sido o limite dos avanços metapsicológicos por ele propostos antes de sua morte. Contudo, Zaltzman (1996) faz dessa declaração de Freud o mote para propor haver um último "remanejamento" metapsicológico. Propõe que o ensaio testamentário "Moisés e o monoteísmo" (1939 [1934-1938]/2018), teria trazido uma novidade que retroagiria sobre toda a metapsicologia. Uma nova luz surgia frente às perspectivas desanimadoras para a prática analítica que seu criador anunciara. Apresentaremos tal discussão no segundo capítulo. Antes, veremos como a teoria pulsional evoluiu até a introdução da pulsão de morte e, posteriormente, a apreensão desse conceito por Zaltzman.

\section{2 \\ Da pulsão sexual às pulsões de morte}

Dentre as grandes categorias da vida psíquica, a pulsão é considerada um dos conceitos fundamentais do edifício metapsicológico. Inicialmente, expressava apenas a existência de necessidades sexuais no ser humano, cuja energia, a libido, impeliria a um objeto junto ao qual se realizaria a descarga (FREUD, 1905/2016). Tratava-se de uma força subversiva, disruptiva, não apreensível pelo eu consciente e sempre em busca de descarga. Uma quantidade de tendência pulsional, contudo, permaneceria no Eu, se diferenciando da libido (pulsão sexual voltada ao objeto), de modo a se defender, se preservar da impetuosidade da pulsão sexual no cumprimento da descarga. Esta dualidade - pulsões do Eu ou de autoconservação pulsões sexuais - consistiu na primeira teoria pulsional.

Na década de 1910, afirma-se a ideia de um originário investimento libidinal do Eu, a partir do qual uma parcela é depois cedida aos objetos. Compreende-se que as pulsões do Eu comportam um montante sexual, obrigando a uma mudança de concepção, que passa a estabelecer a dualidade pulsões do Eu - pulsões do objeto (FREUD, 1914/2016). No mesmo período, ao esmiuçar o conceito de pulsão em 
"Os instintos e seus destinos"1, Freud (1915d/2016) esclarece não haver diferenças qualitativas entre as pulsões, sendo a diferença entre as diversas correntes oriunda da magnitude das excitações e da função que exercem. "O que diferencia as operações psíquicas dos instintos entre si pode ser relacionado à variedade das fontes instintuais. No entanto, apenas num outro contexto poderá ser discutido o problema da qualidade do instinto" (FREUD, 1915d/2016, p. 60). Vemos que a ideia de uma dualidade precisava ser mantida de alguma forma, pois era a explicação e fundamento do aparelho psíquico e seus mecanismos, dos quais resultavam os conflitos e as manifestações patológicas.

No final da mesma década, como decorrência das novas dificuldades apresentadas pela clínica, desta vez ao revelar formas repetitivas de sofrimento que apontavam para a compulsão à repetição e para a fixação na dor, Freud (1920/2010) postula a existência da pulsão de morte. Tal conceito se impõe como necessário à compreensão da existência de um além do princípio do prazer denunciado pelas observações clínicas. Passa, então, a compor o dualismo pulsional, sendo uma tendência contrária à pulsão sexual ou de vida, a qual engloba as pulsões de autoconservação, diferentes da pulsão sexual mesmo que tenham um fator libidinal em comum.

A suposição de uma pulsão de morte ou de destruição encontrou resistência e oposição até mesmo nos círculos psicanalíticos (FREUD, 1930/2010). Além de resistência, a apresentação de tal hipótese permitiu, dentre os psicanalistas que a acolheram, diferentes abordagens, conforme o relevo conferido a determinadas passagens do texto freudiano. É possível apreendê-la, tal qual é anunciada, como impulso a restaurar um estágio anterior do vivo, que, ao fim, seria a própria morte, retorno ao inorgânico - sustentando o princípio da inércia e a compulsão à repetição, não detectáveis na pulsão sexual (FREUD, 1920/2010).

\footnotetext{
${ }^{1} \mathrm{O}$ tradutor da edição das Obras completas de Freud da editora Cia das Letras, aqui utilizada, preferiu o termo instinto à pulsão. Em "As palavras de Freud" (SOUZA, 1998), o mesmo autor faz uma extensa justificativa para tal escolha, podendo tal obra ser consultada caso o leitor se interesse. Outros autores como Laplanche \& Pontalis (1968) e Eksterman (1985) apontam que o termo "pulsão" seria a tradução mais correta. Os primeiros, por entenderem que o termo "instinto" qualificaria um comportamento animal hereditário, próprio da espécie, sendo a "pulsão" inequivocamente humana, conceito-limite entre o somático e o psíquico. Já o segundo autor considera que apenas o termo "pulsão" remete a um impulso ao objeto, segundo um objetivo. Seguimos a indicação desses últimos, só utilizando "instinto" nas citações literais.
} 
Revela-se, assim, como “[...] tendência ou esforço da vida psíquica em diminuir, manter constante, abolir a tensão interna dos estímulos" (FREUD, 1920/2010, p. 228), sendo essa última a tendência que melhor expressaria o retorno ao inanimado visado pela pulsão de morte (KLIER, 2012). O caráter conservador e regressivo levou Freud (1920/2010) a especular que a pulsão de morte seria o impulso mais primitivo e original do ser vivo, tendo a pulsão sexual se manifestado apenas posteriormente, frente aos obstáculos que a vida impunha ao retorno ao inorgânico. Segundo David-Menard (2015), Freud denomina “pulsão de morte” um horizonte original contra o qual lutaria a ligação desprazerosa que se produz na proximidade de um risco de morte do aparelho psíquico. O “além” do princípio do prazer seria essa ligação que não visa, ainda, a descarga, mas luta contra o desligamento máximo que se chama morte.

Mas a partir do ensaio “A negação” (FREUD, 1925/2011), acompanhamos uma transformação do conceito de pulsão de morte. Ela passaria a ser responsável, nos primórdios da vida do infans, pela separação e constituição do objeto, sendo considerada o princípio de constituição desse e responsável pela estruturação do psiquismo. Explicita-se, desta vez, uma vinculação dos conceitos de ligação e desligamento, enquanto atividades psíquicas, às pulsões como forças que estruturam o aparelho (GARCIA-ROZA, 1986). A primeira expulsão que o infans estabelece ao ser afastado da mãe é realizada pela pulsão de morte e dá origem à negação enquanto função simbólica. Freud estabelece que "a afirmação - como substituto da união - pertence a Eros, a negação - sucessora da expulsão - ao instinto de destruição" (FREUD, 1925/2011, p. 281).

Garcia-Roza (1986) assegura que os processos de introjeção e expulsão são correlativos, nos primórdios de um sujeito, dos processos de constituição do Eu e do objeto, e se fazem tanto pela ação da pulsão de vida - como pulsão de unificação -, quanto pela pulsão de morte - como pulsão de desunião -, responsável pela separação da criança em relação ao objeto primordial. Essa perspectiva permite abordagens que se afastam da ideia estrita de retorno ao inanimado, e os eventos decorrentes do desligamento do objeto primordial, ao contrário, podem ser considerados como responsável pela estruturação do psiquismo. 
Posteriormente, constatamos em "Mal-estar na civilização" (FREUD, 1930/2010) que, domada e moderada, potencialmente inibida em sua meta, a pulsão de morte, dirigida aos objetos, poderia "[...] proporcionar ao Eu a satisfação das suas necessidades vitais e o domínio sobre a natureza" (FREUD, 1930/2010, p. 8990). Além disso, até mesmo ao aparecer na cega fúria destruidora, “[...] está ligada a um prazer narcísico extraordinariamente elevado, pois mostra ao Eu a realização de seus antigos desejos de onipotência”. Deste modo, mesmo não vinculada aos impulsos sexuais, tal força poderia potencializar a vida.

Conforme manuscrito inédito recém-publicado, sem título (FREUD, 1931/2017), a pulsão de morte se dá a conhecer como impulso à agressão e à destruição, sendo a nomenclatura pulsão de morte referida ao que seria a tendência final dessa pulsão. Na 32 $2^{\mathrm{a}}$ das "Novas conferências introdutórias" (FREUD, 1933b/2010) são propostas duas condições para que a pulsão de destruição seja apreendida ou percebia: a primeira delas, quando aparece ligada às pulsões eróticas, no masoquismo; a segunda, em maior ou menor grau ligada ao erotismo, ao se voltar contra o mundo externo, podendo retroceder como autodestruição no caso de encontrar obstáculos à realização externa. Em “Análise terminável e interminável” (FREUD, 1937a/2018, p. 311-312), agressão ou destruição são reconhecidas como derivados psíquicos da pulsão de morte, a qual, por sua vez, diria respeito à tendência presente na matéria viva.

Em seu derradeiro ensaio técnico, "Esboço de psicanálise", publicado postumamente já na década de 1940, Freud (1940 [1938]a/2018, p. 196) é cauteloso ao dizer que "[...] no caso do instinto de destruição, podemos imaginar que sua meta derradeira seria fazer o que é vivo passar ao estado inorgânico". Considerando os enunciados anteriores de que a pulsão de destruição se tratava da manifestação psíquica e que a pulsão de morte dizia respeito à força presente na matéria viva (FREUD, 1937a/2018), é admissível considerarmos que a "meta derradeira" coincide com a tendência ao inanimado da matéria viva. Confirmar-se-ia, então, que a proposta de retorno ao inanimado não se trata da hipótese de manifestação psíquica, sendo esta algo que "se dá a conhecer" (FREUD, 1931/2017, p. 47), que pode ser observada, como a agressão, a destruição. 
$\mathrm{Na} 32^{\mathrm{a}}$ das "Novas conferências introdutórias" (FREUD, 1933b/2010) parece não restar dúvida para esse fato frente à afirmação de que as pulsões não governam apenas a vida psíquica, mas também a vida vegetativa. Essas pulsões orgânicas se revelariam como empenho em restaurar um estado anterior.

Lacan (1960/1997) preferiu o termo "vontade de destruição" à tendência ao inanimado. Em sua apreciação sobre a pulsão de morte, privilegia a dimensão psíquica do constructo, reafirmando ser o retorno ao inanimado uma ideia correspondente a certa tendência dos sistemas materiais vivos. Ao ingressar no aparelho psíquico, esta força se manifestaria como vontade de outra coisa, afastando inclusive a ideia de agressão, o que seria um resultado secundário da vontade de destruição.

Enquanto impulso à destruição, a pulsão de morte poderia ser observada, constatada, mas a morte propriamente dita seria potencialmente apenas uma das consequências desta atividade pulsional no aparelho psíquico. Não significa que Freud tenha abandonado a hipótese de retorno ao inorgânico, a qual constatamos até seu último ensaio. Contudo, ali parece mesmo reservá-la para se referir a uma tendência da matéria viva, de modo que é preciso cautela ao considerá-la na perspectiva do aparato psíquico, não associando-a somente à finitude da vida. Nos interessa que, como trabalho de destruição ou, mais precisamente, de desligamento, esta pulsão passa a ser um importante operador na prática analítica, conforme veremos Zaltzman defender. E é considerando as tendências à ligação e ao desligamento que a autora aborda as pulsões de vida e de morte, evitando uma substancialização desses conceitos.

Diferente da apresentação de 1920, que recorre às forças atuantes na matéria viva cuja tendência é levá-la à morte, retornando ao inanimado, a partir de 1925 vemos a abertura para concepções que se separam da ideia de morte estritamente vinculada ao fim da vida. Essas destacam a atuação das pulsões no aparelho psíquico e não na matéria viva. Assim, é importante que consideremos, para esse último caso, a vida do simbólico, das relações, da representação, o que melhor se adequaria à dimensão psíquica das forças pulsionais. Nesse sentido, a pulsão de morte poderia ser apreendida também como força que destrói tendências estanques. Até mesmo processos como a memória poderiam ser encarados como 
empreendimentos precários, sempre sujeitos à implosão pela força da pulsão de morte (SALZTRAGER, 2012), dando lugar a novas construções, novas representações.

Indo ao encontro de tal leitura, Oliveira, Winograd e Fortes (2016) apontam que em um psiquismo fora de perigo, constituindo um Eu robusto, a pulsão de morte seria um incômodo necessário à mudança e desestabilização da "cultura do mesmo", ao passo que o excesso de Eros causaria alienação e imobilidade.

Fortes (2012) ressalta o aspecto paradoxal da pulsão de morte, que pode ser vista tanto pela via da tendência à descarga total quanto pela via do excesso que pressiona e perturba o psiquismo, obrigando-o sempre a se mover. Para a autora, não seria necessário priorizarmos uma vertente ou outra, mas apresentá-las como o próprio paradoxo da pulsão, demonstrando a envergadura do conceito no legado de Freud.

A obra de Zaltzman (1979/1994, 1988/2008, 1996) comparece como uma referência para esta última perspectiva. Ao avançar com a proposta que encontramos a partir de "A negação" (FREUD, 1925/2011), a autora considera que “destruir", ou a ação de desligamento efetuada pela pulsão de morte, além de possibilitar a eclosão e renovação de formas de vida constituídas, pode ser apreendida também num viés de protesto vital, permitindo dar fim a situações que anunciam o risco de morte. Em contextos onde tal ação não é possível, pode comparecer na forma de resistência, reduzindo a vida a ligações mínimas necessárias para que se possa sobreviver. Para a psicanalista, “[...] falar de uma pulsão de morte única, cega, mortífera, só funcionando numa direção - contra a vida - trai a importância do conceito e a expansão do funcionamento desta categoria pulsional” (ZALTZMAN, 1979/1994, p. 59).

Veremos, então, a autora dar visibilidade às manifestações em forma de protesto e, em seguida, aos "inúmeros fatos da vida psíquica normal [que] exigem uma explicação desse tipo" (FREUD, 1937a/2018, p. 312), se exercendo de diversas maneiras no mundo exterior ou se voltando contra o sujeito em sua vida psíquica e física.

Scarfone (2011) indica que a preocupação maior de Freud teria sido inserir a morte na vida e não apenas especular um substancialismo e uma polaridade 
pulsionais. E Zaltzman acompanha Freud nesse aspecto. Mas o que desponta como diferença no pensamento da autora é a demonstração de que a morte não é apenas o contrário, tampouco o fim, da vida. A morte também está a serviço da vida. Esta se apresenta como a mais relevante contribuição de Zaltzman ao conceito de pulsão de morte. Nosso intuito maior neste capítulo, como já temos demonstrado, é desvelar esse aspecto do pensamento da autora, o que será efetivado a partir do tópico seguinte. Outras proposições, que enriquecem as concepções contidas nos ensaios de Freud, serão desenvolvidas na continuidade do primeiro capítulo.

\section{3}

\section{A pulsão de morte como protesto vital}

A pulsão de morte como força de desligamento que pode promover, para além da agressividade, a complexificação do psiquismo e a destruição de formas previamente estabelecidas de vida. Esse foi um aspecto importante da teoria que Zaltzman iluminou ao considerar a atuação de Tânatos contra as ligações e o trabalho de união de Eros. Em "A pulsão anarquista", ao se referir à pulsão de morte, ela propõe que:

Ao lado do que se entende habitualmente por este termo, ou seja, um fluxo de energia livre realizando por descarga direta a supressão de toda tensão e instaurando assim, ao menos momentaneamente, uma suspensão da vida, ou sob a forma de energia ligada, realizando por fluxos agressivos e auto agressivos sua missão de destruição, é preciso reconhecer outras formas 'demoníacas' que se afastam das vias banalizadas e contribuem à vida psíquica e não à destruição (ZALTZMAN, 1979/1994, p. 59).

Mas a ideia de pulsão anarquista está um pouco além dessa concepção na medida em que afronta diretamente a morte. Esse é o destaque que devemos dar ao conceito. Trata-se de conceber formas de atuação de Tânatos que visam à ruína de relações aprisionadas a uma identidade unificante, com o objetivo de "[...] abrir uma saída vital onde uma situação crítica se fecha sobre um sujeito e o destina à morte" (ZALTZMAN, 1979/1994, p. 61-62). Não significa a desconfiguração da dimensão agressiva, mortífera de Tânatos, mas também não se restringe aos desligamentos cotidianos de sua atividade, o que permitiria a complexificação da vida. Comporta 
a abertura para a atuação na resolução de estados de urgência subjetiva. São situações nas quais o sujeito está exposto ao risco de morte. Isto porque a morte se apresenta como certa, em função do submetimento à crueldade de um outro. Ou, ainda, por estar esquecida em decorrência de um amor totalitário, o que também se torna um risco de que a morte compareça pelas vias disponíveis.

O ambiente mental, natural, social ou político com o qual um indivíduo, ou um grupo, estabelece relações, pode anular a alteridade e torná-lo refém de uma potência arbitrária. Situações assim podem ter início nos laços libidinais, quando uma das partes chega ao ponto de exigir que o outro viva a seu modo. A evasão libidinal, via deslocamento de investimentos ou recuo narcísico, pode ser inoperante e fragilizá-lo ainda mais.

A exigência destruidora que poderia arruinar uma situação como esta e eclodir toda relação fixa, é obra da categoria de pulsão de morte que Zaltzman (1979/1994) nomeou pulsão anarquista. Enquanto anarquista, tal força permite a assunção de uma postura de resistência, rebelião, insubmissão contra poderes opressores e de destruição psíquica e física. "Numa relação de forças sem saída, só uma resistência nascida das próprias fontes pulsionais de morte pode afrontar a ameaça de perigo mortal” (ZALTZMAN, 1979, p. 64).

A proposta de atuação da pulsão de morte como proteção contra a ascendência do outro sobre o indivíduo aparece também no pensamento de Pontalis (1988/2008). O autor reconhece que muitas vezes a distância mínima necessária entre dois sujeitos dá lugar a uma "possessão", quando um corpo estranho interno invade incessantemente, violentamente, exerce uma dominação de dentro, parecendo fazer as vezes da própria pulsão.

Em contrapartida, haveria o esforço enfurecido de controlar tal corpo estranho, colocando-o do lado de fora. O autor trata como uma "pulsão de dominação" que visa a posse do objeto como se fosse uma presa, aparecendo como não sexual, como se a pulsão sexual estivesse confiscada pelo objeto interno prevalente. Ao sujeito só resta reagir. A impotência em situações como essa é a admissão da onipotência do outro, por ele conservada, frente à qual a única resposta possível é reagir. 
Mas o que se exacerba na proposição de Zaltzman é a situação de precariedade do sujeito, que já se vê destinado à morte. A hipótese colocada é de que o movimento anarquista extrai a força da pulsão de morte e a remete contra ela mesma. Deve-se considerar que o referido contexto se trata, sobretudo, de um movimento intrapsíquico, no qual a força de destruição se volta contra ela própria e, em vez de acatar o destino da morte imposto por um outro, transgride, se rebela. A rebeldia pode, muitas vezes, ser absolutamente silenciosa, sem ato. Os prisioneiros dos campos nazistas que resistiam jamais expressavam atos de contestação, o que anteciparia a morte. Sobreviver era o maior ato de rebeldia.

A pulsão de morte trabalha contra formas de vida estabelecidas e contribui para renová-las. O movimento anarquista surge quando toda forma possível de vida desmorona, ele extrai sua força da pulsão de morte e a remete contra ela e sua destruição (ZALTZMAN, 1979/1994, p. 66).

Beetschen (2011) considera se tratar de um apelo à energia dissociativa da pulsão de morte. Esta forneceria ao psiquismo ameaçado de destruição a capacidade de retornar ao seu contrário a violência da destrutividade advinda da ligação ao meio ou de uma massificação narcísica potencialmente mortal. A dissociação e a desordem seriam formas de protesto vital, testemunhando uma força de desligamento posta a serviço da vida. Fortes (2012) também ressalta que no cerne da experiência da morte o sujeito pode encontrar vias de combate às forças mortíferas, ou seja, a "pulsão de morte encontra na própria disrupção a saída vital ante as forças aniquilantes que também a constituem" (FORTES, 2012, p. 111).

A pulsão anarquista exerceria sua atividade de desligamento contra quaisquer situações de domínio mortal. Domínio de Eros e da pulsão de morte do outro, da destrutividade da massa e da autocracia e autossuficiência do Eu. Os impasses do narcisismo são alvos contra os quais se voltaria tal força. Quando não há espaço para identificação a outros humanos ou para o amor, a pulsão anarquista asseguraria a permanência da ligação à comunidade humana, fazendo frente a um narcisismo totalitário (BEETSCHEN, 2011).

As relações fixas, aprisionantes, podem se estabelecer por diversos motivos, com ou sem o consentimento do sujeito. De algumas delas seria impossível evadirse. Zaltzman (1979/1994) destaca duas vivências extremas apresentadas sob o título de experiências-limite: a sobrevivência nos campos de concentração e a vida dos 
esquimós de Thulé, região gélida do Ártico. São exemplos onde o humano se encontra à beira de uma situação psíquica urgente, por escolha ou imposição, a qual não pode atravessar ou afrontar sem prejuízo mortal. São casos onde a pulsão de morte, impedida de se manifestar arruinando a relação, se manifesta como resistência, guardando a condição de escolher viver. A força de insistência na vida, daqueles que não sucumbem, proveria da pulsão anarquista.

A resistência à morte exige, antes de mais nada, o reconhecimento de sua presença. A pulsão anarquista forneceria a força necessária para que o humano não se refugie na recusa, na ilusão. Antelme (1957/2013), sobrevivente do campo de concentração, descreve em "A espécie humana" que, para sobreviver, era preciso aceitar o universo concentracionário, se reconhecer na instância da morte. Se alimentar dos restos de outros passa a ser um ato de grandeza. Conforme a leitura de Cabral e Palumbo (2016), Zaltzman esclarece que, assim como quando Eros torna-se massificador, o excesso de privação arrastaria o sujeito para o limite de uma angústia sufocante, momento em que não há mais heroísmo nem opções que não sejam tentar viver ou se deixar morrer.

Em um debate sobre a obra de Zaltzman, Tysebaert (2011) nos relembra uma personagem da literatura e cinema contemporâneos que ilustra com exatidão o que seria uma vida submetida a poderes repressivos na qual a pulsão anarquista assume o papel de insubmissão à morte. Trata-se de Lisbeth Salander, protagonista da trilogia Millenium, de Stieg Larsson (2007), jovem associal, marginal, às vezes violenta, cuja vida se desencadeia sob os auspícios da transgressão, com a finalidade de exorcizar o perigo mortal derivado de forças internas e externas.

Lisbeth conheceu precocemente a dureza extrema que Zaltzman (1979/1994) chamou experiência-limite. Rotulada erroneamente de esquizofrênica e como um risco à sociedade, foi internada por um longo período em um hospital psiquiátrico infantil, submetida a toda sorte de abusos. Quando liberada do internato, passou a viver de forma nômade, sem fixar-se a lugar algum nem construir laços duráveis. Esses se constituíam apenas eventualmente e sob a ameaça de ruptura iminente. A lucidez do risco, a capacidade de se antecipar, o desafio à ordem e à autoridade seriam todas marcas da atividade de desligamento da pulsão de morte que 
comparecem em Lisbeth, na defesa de uma sobrevivência que superaria a morte psíquica (TYSEBAERT, 2011).

Ao longo da trama, revelam-se mais elementos que explicam a atitude da heroína. Seu pai era um assassino inescrupuloso que traficava mulheres, representando a figura do pai primevo, possuidor do poder absoluto. Lisbeth instaura um duelo de morte com ele, que tenta de todas as formas eliminá-la. Com o auxílio de um filho ainda mais violento, este pai chega a enterrar a protagonista acreditando tê-la assassinado, mas ela sobrevive e volta a afrontá-lo, com o último recurso de energia sobrevivente. O filme, segundo Tysebaert (2011), é uma verdadeira alegoria da energia mobilizada pela pulsão anarquista.

Um aspecto que Zaltzman (1979/1994) destaca, quando a pulsão anarquista surge em situações de precariedade absoluta e a morte ameaça de muito perto, é a prioridade do registro da necessidade com relação ao registro do desejo. Nos campos de concentração o sujeito é forçado a se reconhecer apenas como objeto de extermínio e a resistência a tal desumanização exige o investimento prioritário do registro das necessidades. Honrar a condição humana seria priorizar o registro da necessidade sobre o do desejo.

Quando forças assassinas governam uma vida, sobreviver não admite nostalgias e ternuras. A simpatia e a amizade são consideradas atuações irresponsáveis. As organizações de desejo dão lugar à crueza da necessidade. Reduzido ao extremo despojamento da necessidade, o homem descobre que não precisa de nada além do que a necessidade para, ao negar, em retorno, tudo aquilo que nega a sua própria vida, manter a relação humana em sua primazia. A necessidade é necessidade de viver (ANTELME, 1957/2013). Uma vez que, no registro psíquico, a necessidade puramente biológica já passou por uma representação e investimento de afeto, o que temos é uma experiência entre os limites do vínculo erótico e do funcionamento biológico, a qual só teria sentido já como experiência psíquica.

Ao debater a obra de Zaltzman, Guarnieri (2011) observa que, em determinados contextos, a pulsão anarquista põe em primeiro plano a valência vital do desligamento, liberando o sujeito de ligações internas nas quais um Eros aglutinante o encarceraria, fazendo restar apenas a ligação à vida. É o ponto em que 
a identificação sobrevivente entra em jogo. Se todas as outras ligações foram rompidas, destruídas, anuladas, resta apenas uma ligação fundamental à possibilidade de sobreviver: a ligação ao conjunto humano.

As experiências-limite instauram um embargo à vida psíquica e física do ser humano, o privando de suas defesas e o expondo a uma possibilidade constante de morte. Se Eros e Tânatos trabalham na manutenção do equilíbrio entre os interesses coletivos e individuais no decorrer da vida, em determinados contextos, é a pulsão anarquista que permite a manutenção em vida do ser humano. Do mesmo modo que os movimentos anarquistas, essa pulsão luta contra a autoridade, sobrevivendo ainda que através da desordem e violência, pois “enquanto o poder trabalha para se conservar e expandir, a pulsão anarquista trabalha para fazer tudo isso voar pelos ares" (ZALTZMAN, 1979/1994, p. 68).

Os caçadores de Thulé, conforme relata Malaurie (1958/1975) em "Os últimos reis de Thulé", afrontavam o perigo da morte indo solitariamente à caça de ursos. Zaltzman considera, mais uma vez, que a relação de forças não é apenas entre o homem e o meio, mas entre dois destinos de Tânatos na cena psíquica individual. A hostilidade do meio serve apenas de suporte para as forças hostis. A natureza, sem aspirações de morte, obriga o sujeito a reconhecer a relação de forças internas não mediadas pela libido. Quando o exorcismo da morte por esta via não era possível, como no caso das mulheres e adolescentes, despreparados para a caça, eram possuídos pela "perdlérorpoq". Essa seria uma crise na qual o sujeito rasgava suas roupas, lançava-se à natureza, corria sobre os blocos de gelo no mar, como forma de exorcizar a presença da morte. Estavam, para os esquimós, doentes da vida.

\section{4}

\section{A pulsão de morte na vida cotidiana}

A pulsão anarquista foi um dos vieses possíveis de manifestação da pulsão de morte que Zaltzman (1979/1994) pretendeu dar visibilidade. Entretanto, faz-se necessário compreender esse aspecto em sua singularidade e especificidade. É digno de nota do fato de a autora não retornar a essa proposição em muitos de seus 
trabalhos posteriores nos quais aborda a temática da pulsão de morte. A pulsão anarquista, conforme pudemos apreendê-la, está referida a situações de precariedade, ao submetimento extremo do sujeito a forças maiores, ao risco real de morte etc. Remete à necessidade de rebeldia contra certas imposições. Daí a escolha do termo anarquista, pois se refere a uma atividade "desobrigante", de recusa a uma autoridade mortífera, como foram os movimentos anarquistas que defenderam o livre arbítrio individual em oposição às correntes autoritárias da sociedade.

No entanto, não foi apenas a esse quinhão da pulsão de morte que a autora se dedicou em seus escritos. Ainda em seu primeiro trabalho, se propôs a descrever situações do cotidiano, que se repetem na relação transferencial, decorrentes da pulsão de morte. Uma delas diz respeito àqueles sujeitos que só podem estabelecer um laço que perdure sob a ameaça constante de ruptura.

Quando são pacientes em análise, tal ideia deve ser mantida intocável para que não compareça em ato, com o seu desaparecimento das sessões. Além da possibilidade de se envolver em acidentes, adoecer, provocando o rompimento do trabalho. Deste modo, a ameaça de romper, desistir, é constante e não deve ser colocada em questão (ZALTZMAN, 1979/1994). Qualquer tentativa de fortalecer o laço pode ser insuportável para aqueles que escolhem a instabilidade e só a iminência de ruptura pode conservar a duração da análise.

Beetschen (2011) entende que, na leitura de Zaltzman, a tarefa de individuação da pulsão de morte, a conquista de autonomia pelo sujeito, exige esta ameaça de ruptura, ou seja, que o desligamento esteja sempre presente para que relações duradouras possam se estabelecer por meio da ligação.

Acompanhando com a autora ilustrações da vida e da clínica, caminhamos pelas possibilidades do trabalho psíquico de Tânatos sem efeitos mortíferos. São exemplos que todos nós vivenciamos cotidianamente, como o cansaço que abate sem causa imediata, o tédio que surge quando esperávamos a euforia, a acumulação de pequenas catástrofes. Incidentes que não entram nos esquemas clássicos de auto ou hétero-agressividade ou destruição, mas indicam a ação das pulsões de morte, "numa atividade que circula sem cessar sobre a cena psíquica e sobre a cena do mundo" (ZALTZMAN, 1979/1994, p. 28). A autora demonstra o olhar aguçado ao 
qual Freud (1937a/2018) se referiu, necessário para se observar inúmeros fatos da vida psíquica normal explicados pela atuação da força em questão.

Seres desordenados carregariam a marca de Tânatos, ao imprimir mudanças de identidade, forçar rupturas, escolher sempre situações dramáticas e traumáticas, viver na errância etc. Blanchot (1986/2007) também aborda esses tipos de escolha questionando se a vida nômade não seria, em vez de eterna privação de uma estada, a autêntica forma de residir sem estar preso à determinação de um lugar ou realidade permanentes.

É possível identificarmos, nos tipos apresentados por Zaltzman (1979/1994), aqueles pacientes que demonstram sentimento de desdém, expressando uma solidão irredutível. Pessoas que farejam ou criam catástrofes, cujas vidas soam sempre cheias de riscos. Mudanças, transtornos, rupturas são formas de se agitarem à procura de um apaziguamento inalcançável, posto que se opõem ao que, verdadeiramente, interessa: "verificar até que ponto não se apegam a nada e a ninguém" (ZALTZMAN, 1979/1994, p. 36).

\section{5 \\ O risco de morrer na luta por viver}

Existem manifestações nas quais, como protesto vital, a pulsão anarquista poderia expor o humano a outros riscos de morte. A pulsão de morte, nestes casos, torna o perigo interior de morte maior do que o poder de fazer dele uma forma de vida. Há, nestas circunstâncias, risco real de morte e a pulsão pode encontrar, em situações de exposição, alimento para sua finalidade.

Tais manifestações, sob a égide da pulsão de morte, são mais comuns na literatura analítica: bulimia, anorexia, façanhas físicas em busca dos limites do esgotamento, fascinação por exposição ao perigo, confronto com os limites da resistência física. São todas expressões clínicas que Zaltzman (1979/1994) não concebe possível intervir sem considerar a atividade da pulsão de morte.

Apesar do flerte com a morte, a autora considera que, psiquicamente, é a dimensão de sobrevivência que tais manifestações revelam, pois é ela que é visada, nestes casos, e não necessariamente a morte. A urgência na demonstração de que 
se está vivo, se expondo à morte, toma lugar na dimensão do respeito pela realidade biológica.

O recurso aos limites do corpo é, às vezes, o único que resta a um sujeito para se subtrair ao excesso de ascendência mental de um outro, a uma ascendência mental potencialmente mortífera, porque exclusiva de uma escolha ou de uma recusa da vida apropriada por um outro que não o sujeito (ZALTZMAN, 1979/1994, p. 50).

A psicanalista nos questiona, contudo, se podemos qualificar alguns destes destinos como patológicos. Se refere àquelas pessoas que só conseguem sentir gosto pela vida através do risco. Ao mesmo tempo, dentre elas estão as que realizam façanhas incompatíveis com as trajetórias razoáveis das vidas que se poupam. Quando alguém procurar uma análise com questões dessa ordem, o perigo de morte superou o poder de fazê-lo uma forma de vida.

Em outros casos, como nas anorexias e bulimias, pode se tratar de uma resistência à anulação de si que se manifesta pela greve de uma função vital e greve mental do apetite de viver. Por esta via, possível de se reconhecer como uma das formas da pulsão anarquista, o anoréxico procuraria superar a experiência-limite que o impeliu. Na tentativa de se desfazer do "alimento-amor" obrigatório que anula a si próprio, o que se rompe é a apetência pela vida. Em resistência a esta anulação de si emerge a greve de uma função vital e mental. $\mathrm{O}$ anoréxico pode morrer ao tentar viver (ZALTZMAN, 1979/1994).

Ao final deste capítulo, evidenciamos o quanto os aspectos investigados como, por exemplo, a resistência em situações de submetimento, o registro da necessidade se sobrepondo ao desejo, os adoecimentos do corpo como tentativa de autonomia frente ao outro, revelam a atividade incessante da pulsão de morte no funcionamento psíquico. Considerada força atuante desde os primórdios da constituição psíquica, esta se mostra reveladora de uma dimensão negligenciada do funcionamento pulsional até 1920.

Ao longo dos tópicos foi possível acompanhar as contribuições, inovadoras e/ou afirmativas, de Zaltzman, acerca do funcionamento da pulsão de morte no psiquismo. Foi a via pela qual pudemos revelar o viés transgressivo das proposições da autora ao rever a metapsicologia, na forma de protesto vital e esforço para assegurar a sobrevivência. Foi possível perceber como a pulsão de morte, sua 
tendência de desligamento, comparece de modo ruidoso no psiquismo humano, o que interessa sobretudo à atividade clínica. No capítulo seguinte, veremos como este protagonismo deve ser consignado na clínica. Caso contrário, adverte Zaltzman (1996), não estando o analista atento para esta atividade pulsional constante, não haveria avanço no trabalho de cura ou, ainda mais grave, atrapalharia e até pioraria o estado de um paciente. 


\section{3 \\ Pulsão de morte e a transgressividade da clínica}

Ao apresentar suas contribuições ao conceito de pulsão de morte, avaliandoo sobretudo sob a forma transgressiva das pulsões anarquistas, conforme acompanhamos no primeiro capítulo, Zaltzman (1979/1994) visava, primordialmente, sugerir novas possibilidades e subsídios à atividade clínica. Esta é a discussão que aprofundaremos neste capítulo. Inicialmente, retomamos um questionamento que a autora faz acerca da concepção de representação na obra de Freud. Se a clínica exige que o sujeito manifeste seu sofrimento por meio da linguagem, esta seria a única forma possível de intervir sobre o mal-estar decorrente da pulsão de morte. Neste panorama, a autora indica ser necessário rever a concepção relativa à falta de representação de tal força no psiquismo. Veremos como isso é colocado por ela e a compreensão a qual foi possível chegarmos recorrendo a proposições de comentadores da sua obra e de outros autores.

A partir daí, investigamos a reconsideração da atividade de Tânatos na prática da psicanálise. Quanto a isso, o mais longe que vimos Freud levar a discussão, já em seu último ensaio sobre a técnica, "Compêndio de psicanálise” (FREUD, 1940 [1938]a/2018), foi supor uma forma de resistência à análise cujos meios de que dispunha a psicanálise eram insatisfatórios a combater. No texto, ele se refere a pacientes que visavam à autodestruição, alguns podendo chegar a cometer suicídio. Seriam situações nas quais haveria uma liberação de quantidades excessivas de pulsão destrutiva, disjuntas da pulsão sexual, voltando-se contra eles próprios. Esses pacientes não apresentariam melhoras quando em análise. Freud, portanto, encerra sua produção teórica confessando se tratar de casos que ainda não conseguia explicar completamente.

É a partir do viés de resistência à análise apontado por ele que Zaltzman (1986/1999), em mais uma demonstração das apostas transgressivas de seu pensamento, procura ampliar o campo de possibilidades no manejo de casos onde prepondera a atividade da pulsão de morte. Tal proposta emerge de indicações contidas nos textos do próprio Freud, principalmente em seus ensaios antropológicos como, por exemplo, Totem e tabu (FREUD, 1912-13/2012) e Moisés e o monoteísmo (FREUD, 1939 [1934-1938]). 
O retorno aos postulados dos textos antropológicos de Freud comparece como a última reflexão da autora que propomos investigar neste capítulo. A partir deles, concepções mais otimistas quanto à intervenção nas manifestações de Tânatos poderiam ser elaboradas. Zaltzman (1986/1999) nos convoca a apreender como Freud vincula o psíquico individual a uma estrutura maior, de dimensões coletivas, aspecto que ganha enorme importância nos ensaios que ela produziu a partir da década de 1980. Ratifica então que a cura em psicanálise só é possível ao considerarmos o psiquismo individual como partícula de uma estrutura maior, pertencente ao grupo humano, sendo a análise um processo que, ao transformar o sujeito, também transformaria o grupo.

\section{1}

\section{A representação da pulsão de morte}

Foi somente nos ensaios finais de sua obra que Freud (1937a/2018) deixou claro não ser correto limitarmos a atividade da pulsão de morte à observação de materiais patológicos, sendo inúmeros os fatos da vida psíquica normal explicados por essa atividade. Ressaltou que, no futuro, analistas atentos poderiam expressar de modo mais claro a variedade de observações das manifestações da pulsão de morte nos fatos da vida, afinal era um tema ainda muito novo por ele explorado. A obra de Zaltzman, sobretudo seus exemplos clínicos, confirmaram as previsões de Freud. Vemos nos trabalhos da autora uma dilatação do conceito a partir do retorno aos trabalhos de seu fundador, o que a levou, inclusive, a questionar alguns de seus pressupostos.

Um dos principais questionamentos se refere à ausência de representação daquele construto. Zaltzman (1988/2008) considera que as pulsões de morte possuem seus modos próprios de representação, nem sempre comparecendo como “essencialmente mudas" (FREUD, 1923/2011, p. 58) ou sendo observadas apenas nas contribuições sádicas a Eros. "As figurações da atividade das pulsões de morte abundam [...]" e "[...] não apenas tomam formas de empréstimo à esfera libidinal" (ZALTZMAN, 1988/2008, p. 89-90, tradução nossa). 
A questão da representação, Vorstellung, segundo Eksterman (1987), é o tema central do universo metapsicológico, indicando algo que se apresenta na mente subsequentemente à ausência do objeto sensorial percebido do mundo exterior, tratando-se de um "fantasiar". Freud teria concebido algo que linguisticamente não faz sentido, mas, que, para ele, fez todo sentido, o "imaginar inconsciente". A impressão sensorial produz inicialmente um rastro de Vorstellung, criação mental de um objeto ausente que pode advir da realidade externa ou interna. Ambas produzem representações, fornecendo as primeiras matrizes simbólicas que produzem informações necessárias aos mecanismos adaptativos.

Esta representação primitiva transforma-se em saber consciente ao se ligar à palavra, abrindo novas possibilidades. A representação primitiva é a linguagem do processo primário de pensar e a representação ligada à palavra é a linguagem do processo secundário de pensar (FREUD, 1900/1969). A palavra distingue o que é consciente do que é inconsciente, o que faz do aspecto topográfico mais uma questão de conteúdo verbal do que de localização espacial. No sistema inconsciente, a representação é "representação de coisa" enquanto no consciente é "representação de palavra".

Segundo Eksterman (1987), do ponto de vista tópico, o que não se representa não existe. Deste modo, a representação do impulso não coincide com o próprio impulso, do mesmo modo que a percepção não é idêntica à sensação. A realidade psíquica não é uma realidade sensorial, mas uma recriação do mundo externo e interno. A pulsão seria a força motriz da representação do impulso biológico. Contudo, "poderíamos objetar com a concepção expressa por Freud de que o impulso de morte não tem representação, ao que poderíamos contra objetar que utiliza as representações de Eros" (EKSTERMAN, 1987. p. 131).

Em "Une volonté de mort", Zaltzman (1988/2008) propõe a reconsideração do caráter não representável das pulsões de morte quando disjuntas das pulsões sexuais. Concebê-las assim as tornariam responsáveis apenas pelo engendramento da compulsão à repetição ou exigiria o conceito sobressalente de pulsões destruidoras, às quais seriam atribuídos seus efeitos tangíveis, o que não se alinharia ao pensamento da autora. Sua argumentação se desencadeia a partir de fatos clínicos e situações da vida que remetem ao que seriam representações daquele construto. 
Concorda que a ação de Eros é unificante, uma atividade de ligação e a ação de Tânatos é desorganizadora, desagregadora. Contudo, não concorda em “[...] ocultála em uma apresentação e desenvolvimento ordenados" (ZALTZMAN, 1979/1994, p. 21).

Para a autora, os argumentos de Freud que tomam a pulsão de morte como silenciosa se mostrariam contraditórios, uma vez que, ao mesmo tempo que o autor atribui uma origem própria e até mais primitiva às pulsões de morte no psiquismo, insiste em não reconhecer nelas mais que um modo de figuração de empréstimo às representações advindas das pulsões sexuais (ZALTZMAN, 1988/2008). Assim ele se expressa: “[...] se não quisermos abandonar a hipótese de instintos de morte, será preciso conjugá-los a instintos de vida desde o começo" (FREUD, 1920/2010, p. 230). Admite que "outros montantes da mesma força podem estar em ação, de forma livre ou vinculada, não se sabe bem onde" (FREUD, 1937a/2018, p. 311), indicando a dificuldade em se observar o trabalho da pulsão de morte.

O que vemos ao longo da obra de Zaltzman é a demonstração de uma abundância de representações, autônomas ou intrincadas, de Tânatos, das quais se destacam aquelas que comparecem na forma insistente de luta e protesto pela vida (ZALTZMAN, 1979/1994). Não só na clínica, mas no cotidiano de cada um, nos comportamentos associais, nas manifestações explosivas, nos pensamentos de morte, no abandono de pessoas e atividades. Todas essas seriam formas de figuração desta atividade pulsional na busca por descarga (ZALTZMAN, 1988/2008).

A ideia de que a pulsão de morte não atua apenas silenciosamente, mas possui diversas formas de se manifestar, aponta, segundo Tysebaert (2011), uma lacuna revelada por Zaltzman na concepção freudiana das pulsões de morte. Ao concordar com Freud quanto ao mecanismo de ação da pulsão de morte, o desligamento, a psicanalista pretende tornar acessível tal ação, uma vez que "a via analítica 'fiel' à Freud teria deixado incultas as formas específicas de trabalho psíquico das pulsões de morte, recusando a estas seu próprio modo de figurabilidade e a lógica particular de seu funcionamento" (ZALTZMAN, 1979/1994, p. 21). Mas qual seria o modo de representação da pulsão cujo mecanismo de ação é o desligamento? 
Questionamento similar já havia sido feito por Beetschen (2011). O autor interroga sobre como atribuir a tal força, cujo destino não é o da ligação, uma representação não vinculada a Eros. Como pensar em uma atividade de representação que não seja de investimento, ligação ou compromisso com a libido e o princípio do prazer? Não se trataria, nestes casos, de formas de ligação atribuídas a Tânatos que, por definição, é força de desligamento? O autor interpreta que a pulsão de morte no pensamento de Zaltzman, ao se impor como resistência a uma ligação ou ao destruí-la, destacando o espaço deixado ao desligamento, afirma-se por meio de representações individualizantes e libertárias.

Para Lacan (1960/1997), a pulsão de morte deveria ser articulada num nível que só é definível em função da cadeia significante. Seria preciso algo para além da pulsão, de onde ela mesma possa ser apreendida numa rememoração fundamental. Se tudo o que é imanente ou implícito na cadeia dos acontecimentos é submetido a uma pulsão de morte, é somente na medida em que há a cadeia significante.

Neste sentido que deveríamos considerar se tratar de uma pulsão de destruição, uma vez que ela põe em causa tudo o que existe. Seria, ao mesmo tempo, vontade de criação a partir do "nada", vontade de recomeçar, o que só poderia ser registrado na cadeia significante (LACAN, 1960/1997). Se trata do mesmo ponto de vista apontado por Beetschen (2011) quanto ao espaço possível deixado ao desligamento, através do qual a pulsão de morte se afirmaria.

Segundo Cabral e Palumbo (2016), considerar a pulsão de morte "sem representação" não significaria falta de linguagem ou de representantes propriamente ditos inconscientes. "Sem representação" indicaria a característica fundamental da tendência da pulsão de morte, ou seja, que ela subjaz a toda forma de rompimento em uma continuidade (ZALTZMAN, 1988/2008). Continuidade de representações, de ideias, de pensamentos, toda sorte de percepções do próprio corpo e de suas zonas de apreciação imagética. Tais percepções seriam captadas por narrativas que silenciam a fala, "deixando ao corpo a tarefa de manifestar suas vontades" (CABRAL E PALUMBO, 2016, p. 89). Esta explicação conciliaria o ponto de vista da autora com o fundamento teórico da representação em Freud, mantendo firme a defesa que ela faz de uma prática analítica que não estivesse 'surda' às manifestações de Tânatos, tampouco as ignorasse. 
Fortes (2012) indica que, se por um lado Eros estabelece ligações do excesso disruptivo da pulsão de morte, esta, por sua vez, rompe as ligações feitas por Eros, funcionando como força disruptiva das ligações estabilizadas. Permitiria, então, novas ligações e abriria portas para a chegada do novo, propiciando a mudança. Seria a face de renovação e transformação, alimentada pela mesma fonte que os impulsos mortíferos, qual seja, o aspecto disruptivo e fragmentário da pulsão de morte.

Reforçando o mesmo ponto de vista, Oliveira, Winograd e Fortes (2016) esclarecem que a pulsão de morte introduziria a diferença no psiquismo, enquanto "representante de energia livre sem representação" (OLIVEIRA, WINOGRAD E FORTES, 2016 p. 86). As rupturas tanáticas defenderiam o psiquismo do excesso de Eros e, subsequentemente, da alienação, imobilidade e indiferenciação dele decorrentes.

\section{2 \\ Crítica à exclusividade do sexual}

Desde seu primeiro ensaio, a grande preocupação de Zaltzman (1979/1994) foi demonstrar como é crucial para a clínica psicanalítica rever o papel atribuído a Tânatos no funcionamento psíquico e, por consequência, no manejo transferencial. Toda a argumentação apresentada ao longo daquela obra é ilustrada por um caso clínico, que veremos à frente, no qual a condução considera a preponderância da atividade da pulsão de morte na vida de uma paciente.

Neste panorama, não se trataria de desconsiderar o papel dos conflitos da psicossexualidade no adoecimento neurótico, mas, sim, de compreender que o malestar humano não se limita a eles. Quase uma década depois, insistindo na importância da pulsão de morte para a clínica, Zaltzman (1986/1999) constata persistir a grande dificuldade dos analistas de reconsiderar, em sua prática, o porte inicialmente ilimitado que Freud (1905/2016) deu à sexualidade e sua função determinante nas formações psíquicas passíveis da influência pela psicanálise.

Ainda hoje notamos tal dificuldade, que se justifica ao considerarmos a história do método analítico. A psicanálise surge e se estrutura como disciplina dedicada a conhecer e intervir no sofrimento humano decorrente da sexualidade. 
Foi a partir de seu trabalho com as histéricas que Freud (1893-1895/1969) iniciou a construção de hipóteses acerca do adoecimento psíquico, vindo a instituir as neuroses como toda forma de manifestação de sofrimento psíquico cuja etiologia estaria ligada a fatores sexuais. Para ele, fatores sexuais diferentes produziriam quadros diferentes de doenças neuróticas e a terapia psicanalítica visava eliminar a sintomatologia dos estados mórbidos causados pela neurose.

Os sintomas compareceriam como satisfações substitutivas do conteúdo sexual não admitido conscientemente, sendo submetido ao mecanismo do recalque. Por recalque indicamos um dos destinos possíveis para o impulso pulsional à medida que este encontra resistências que o tornam, de certa forma, inoperante. Consiste, essencialmente, em rejeitar e manter algo afastado da consciência. Tal processo ocorre quando a satisfação do impulso é inconciliável com outras exigências, de modo que geraria prazer em um sistema do aparelho psíquico e desprazer em outro. A condição do recalque seria o motivo de o desprazer adquirir maior poder que o prazer da satisfação (FREUD, 1915c/2010). O trabalho terapêutico consistiria, então, em afrouxar o recalque, trazendo os conteúdos censurados à consciência, o que redundaria na eliminação dos sintomas.

Mas o "afrouxamento" do recalque nem sempre era alcançado. Foi estabelecendo mudanças nos objetivos da técnica psicanalítica frente aos impasses no tratamento que Freud (1920/2010) chegou ao reconhecimento da compulsão à repetição. Mais de 25 anos já haviam se passado quando novas descobertas, que desviavam o olhar da sexualidade, começaram a despontar e tomar lugar na interpretação dos sofrimentos psíquicos, mas, sempre, ocupando uma posição secundária, visando ao alcance do conflito originário da neurose, sempre de ordem sexual. O ponto de partida para tal deslocamento foi a observação de uma insistência no sofrimento por parte dos pacientes e a repetição dos sintomas, fatos que deram origem à análise da transferência, como veremos a seguir.

De início a análise consistia em uma arte de interpretação, cuja tarefa terapêutica era descobrir, reunir e comunicar o inconsciente oculto ao paciente. Como não surtia efeitos terapêuticos, passou-se a instar o sujeito a confirmar a construção com sua própria lembrança. Mas o analisando nem sempre conseguia lembrar de tudo o que estava recalcado, não se convencendo da justeza da 
construção do analista, acabando por repetir o recalcado em vez de recordar. A repetição teria sempre por conteúdo algo da vida sexual infantil. Além disso, o que se repetia estava inserido na relação do paciente com o terapeuta. (FREUD, 1920/2010).

Tendo sido observada tal dinâmica transferencial, o tratamento passa a se apropriar dela, ou seja, o analista passa a pretender que a antiga neurose seja substituída por uma nova neurose de transferência e se empenha em restringir o campo dessa nova neurose, empurrando-a ao máximo para a recordação, reduzindo a repetição. Seria necessário, em um primeiro momento, que o paciente revivesse, por meio da transferência, parte da vida esquecida, estando tal parte intimamente ligada a vivências de sua sexualidade infantil (FREUD, 1920/2010).

Mesmo após as reformulações da técnica e da teoria, sobretudo a teoria pulsional e a afirmação da existência da pulsão de morte (e o automatismo da repetição daí decorrente), Freud (1920/2010, 1930/2010) mantém os sintomas das neuroses como essencialmente satisfações substitutivas para desejos sexuais não realizados. Propõe, em acréscimo, que toda neurose esconderia um sentimento de culpa inconsciente. Este seria originado a partir do retorno ao Eu da pulsão agressiva que acompanhou a libido em seus empreendimentos, o que fortaleceria os sintomas ao usá-los como castigo. O criador da psicanálise formula, então, que, ao sucumbir ao recalque, os elementos libidinais da pulsão se transformariam em sintomas e os elementos agressivos, decorrentes da pulsão de morte, se transformariam em sentimento de culpa.

Mas o conflito neurótico, eixo da atividade clínica, não seria derivado da oposição entre essas duas correntes pulsionais, se mantendo como uma desavença no campo da libido, tentativa do Eu de se defender dos impulsos libidinais de cunho objetal. Quanto ao sentimento de culpa, Freud (1924a/2011, 1930/2010) afirma ser necessário combatê-lo, mas sempre movido pela intenção terapêutica, ou seja, possibilitar o acesso ao conflito subjacente. Tal combate muitas vezes não surtia efeito, pois a 'política do pior' impedia que o paciente abrisse mão da resistência à análise.

A pulsão de morte comparece, então, cada vez mais como fator de resistência ao restabelecimento durante o tratamento. Em "Compêndio de psicanálise" 
(FREUD, 1940 [1938]a/2018, p. 236), essa atuação se mostra a partir de dois grandes fatores, "reunidos sob a denominação comum: necessidade de doença ou sofrimento". Trata-se do sentimento de culpa, consequência de um Supereu cruel que proibiria o indivíduo de ficar "são", e da liberação de grandes quantidades de pulsão de destruição disjuntas de Eros, que se voltariam para o próprio sujeito. O que Freud deixa em aberto é a questão sobre o papel da pulsão de destruição na própria causação da neurose:

Os sintomas das neuroses são todos, podemos dizer, satisfação substitutiva de algum impulso sexual ou medidas para evitá-lo, geralmente compromisso entre as duas - tais como se dão entre opostos, segundo as leis do inconsciente. A lacuna em nossa teoria não pode ser preenchida atualmente; a decisão é dificultada pelo fato de a maioria dos impulsos da vida sexual não ser de natureza puramente erótica, resultando, isto sim, de amálgamas do instinto sexual com porções do instinto de destruição. Mas não há dúvida de que os instintos que se manifestam fisiologicamente como sexualidade têm papel de destaque, de inesperada magnitude, na causação das neuroses - se esse papel é exclusivo, é algo que fica em aberto (FREUD, 1940 [1938], p. 244).

Embora sem a pretensão de fechar a questão mantida por Freud quanto à causação das neuroses, Zaltzman (1979/1994) se põe a "rastrear", no terreno da prática psicanalítica, a atividade da pulsão de morte. Neste percurso ela observa a necessidade de significativos desvios quanto à primazia do aspecto sexual na conduta clínica, considerando a pulsão de morte tanto no viés mortífero quanto na dimensão de protesto vital. No artigo “Baiser la mort” (ZALTZMAN, 1986/1999) encontramos o cerne de seu questionamento: o fato da psicanálise ser mantida como uma disciplina e prática de gênero único que, penetrando as leis inconscientes que governam a história de cada um, tende a dar voz unicamente à pulsão sexual, eleita exclusiva fonte dos conflitos neuróticos. "Mesmo que o analista não escolha o material associativo que lhe é dado, sua teoria sobre a técnica não é sem consequência sobre suas estratégias interpretativas" (ZALTZMAN, 2007, p. 61, tradução nossa). Segundo a autora, a aliança da prática analítica com a libido e o princípio do prazer não teria cumprido sua promessa de cura.

Ao mesmo tempo que constatamos a primazia dos fatores relacionados à sexualidade, vemos Freud (1933b/2010, p. 262) afirmar, já encerrando a $32^{\mathrm{a}}$ das "Novas conferências introdutórias", que "o que percebemos quanto aos instintos 
sexuais vale em medida igual, ou talvez maior, para os outros instintos, os de agressão [grifo nosso]", se referindo à dificuldade que temos em suportar o pesado fardo psíquico imposto pela civilização. A limitação da agressividade seria o mais duro sacrifício que a sociedade requer do indivíduo e apenas a engenhosa instauração do Supereu conteria os impulsos inclinados à revolta.

Levando tal perspectiva adiante, Zaltzman (1986/1999) pondera haver uma diversidade de sofrimentos hostis como o ódio, o terror, a perseguição, os medos cotidianos, que denunciam certo limite da via exclusiva eleita, a sexualidade, na etiologia dos sofrimentos psíquicos. Não põe em questão o seu papel, mas sua exclusividade. Sendo assim, não apenas a influência nos distúrbios decorrentes de conflitos de ordem sexual deveria ter lugar na prática da psicanálise. Para a psicanalista, com “Além do princípio do prazer” (FREUD, 1920/2010) e a entrada em jogo da existência de uma energia pulsional heterogênea à visada libidinal, novas leituras se impõem à atividade do analista.

Green (1988/1990), do mesmo modo, entende que a força "daimônica" da pulsão de morte se estabelece ao mesmo tempo que é submetida à cegueira que afetara antes o desejo, cujas defesas do Eu se negaram a reconhecer. Zaltzman (1986/1999) considera que, a partir de 1920, a dimensão sexual inconsciente, constatada desde os "Três ensaios sobre a teoria da sexualidade" (Freud, 1905/2016) como recurso de energia mais importante e único constante em todas as manifestações patológicas, perde a exclusividade na prática analítica e deixa de ser o fator único de todos os acometimentos psíquicos. Propõe rever o lugar dado à pulsão de morte como força responsável exclusivamente pelos insucessos terapêuticos, não passível de ser influenciada. Ao contrário, considera que uma das causas do insucesso é justamente a não consideração da pulsão de morte na escuta analítica.

Um aspecto indispensável ao considerarmos o pensamento de Zaltzman quanto às manifestações de Tânatos na clínica é circunscrevê-la como uma atividade de desligamento, não atribuindo nenhum tipo de valor ou qualidade. Isto significa considerarmos que, assim como a pulsão sexual, tal força pode ser tanto negativa (no sentido de patológica, mortífera) quanto positiva (liberadora, resolutiva e terapêutica). Sendo assim, é tão necessária como a pulsão sexual que, 
cumprindo a ligação, pode resultar nas mesmas consequências. Os efeitos de morte e de vida não seriam específicos de uma ou outra força.

Conforme defende Scarfone (2011), melhor seria o emprego dos termos princípio de ligação e desligamento, pois tanto Eros quanto Tânatos podem redundar em vida ou morte, dependendo da dinâmica de funcionamento do psiquismo de cada um e da história que vivencia, devendo sempre vislumbrar um nível de equilíbrio, marca essencial do psíquico humano. $\mathrm{O}$ registro econômico estaria, assim, em primeiro plano, e os efeitos da "maquinaria" pulsional em funcionamento deveriam ser examinados caso a caso para, então, serem atribuídos a uma ou outra corrente pulsional, as quais demandariam posturas diferentes do analista.

Para Zaltzman (1979/1994, 1986/1999), durante um trabalho analítico, a negação da atividade psíquica específica da pulsão de morte e seu impedimento em ser reconhecida, poderia ter graves consequências. Muitas vezes decorrente das resistências do analista, esta falta de escuta forçaria a pulsão a se satisfazer através de formas não essencialmente psíquicas, onde a morte, que teve negado seu estatuto inconsciente, atuaria como materialidade bruta. E na clínica, é esta dimensão bruta que, na maioria das vezes, se anuncia no pedido de socorro do paciente. A morte, o desligamento, exige "acertar as contas" e é melhor que se pague com um tributo mental para não ser preciso pagar em ato.

O manejo da transferência é o que vai permitir o deslocamento dos efeitos de Tânatos, colocando-o a favor da cura. Cabral e Palumbo (2016) ressaltam se tratar de um trabalho clínico não atento somente às vias edípicas do psiquismo explicitadas pelo desejo inconsciente, fadado a um labirinto imaginário de fantasias incestuosas. Os autores localizam na proposta de Zaltzman uma clínica aberta à escuta do desligamento, sendo este último exigido pelas representações inconscientes da morte.

Em um tratamento, então, não seria suficiente buscar as transformações da função sexual para que ela se liberte dos conflitos e encontre algum acordo entre prazer e desejo. Esse trabalho, embora fundamental, não basta. A precariedade do gosto pela vida, adverte Zaltzman (1986/1999), não estaria somente ligada à fragilidade libidinal, à incapacidade de nutrir amor por si próprio e pelo outro, ao 
antagonismo dos amores narcísicos e sexuais. A morte e seu inverso, a manutenção em vida, seriam, para muitos sujeitos, tarefas mais problemáticas do que a sexualidade e de nada adiantaria, nestes casos, insistir em uma direção de tratamento pelo viés da sexualidade. Seria necessário, então, marcar a diferença entre a elaboração da sexualidade e a elaboração da morte.

As ligações afetivas não assegurariam o ser humano contra sua disposição para a morte, que marca um limite ao desejo e insiste sobre a cena psíquica. Zaltzman (1986/1999) considera que a morte tem um protagonismo, independentemente de toda realidade vivida, como a castração existe mesmo sem nunca possivelmente ter existido uma ameaça real. A intrincação pulsional pode ocorrer, mas sempre em duplo senso, na sobreposição das pulsões de morte sobre as pulsões sexuais ou, como é evocado mais frequentemente, na anexação das pulsões de morte pelas pulsões sexuais.

O analista não poderia, dessa forma, escamotear o caráter irredutível e a potência da dupla conflitualidade inconsciente: da função sexual contra ela mesma e da pulsão de morte contra o desejo. Freud (1930/2010) já havia anunciado a dificuldade dos analistas em admitir um conflito para além do âmbito libidinal, sendo atribuído a uma bipolaridade própria do amor tudo o que nele é encontrado de perigoso e hostil. Ele se mostra convencido, no entanto, sobre a autonomia da atividade da pulsão de morte, embora não suscitasse a possibilidade de equipará-la a Eros na formação dos sintomas e no manejo transferencial.

O que se tem é, assim, o modelo do domínio libidinal, da intrincação das pulsões de morte pelas pulsões sexuais e seu triunfo salvador. Mas os conflitos inconscientes e a riqueza de suas combinações transbordariam, na perspectiva de Zaltzman (1979/1994, 1986/1999), sobretudo o binarismo antagônico dos objetivos de Eros e Tânatos. Eros muitas vezes é mortífero, ao passo que Tânatos pode cumprir um papel vital.

Não se trata, deste modo, de opor à promessa de conquista libidinal tudo aquilo que, na análise, trabalharia mais no sentido das operações de perda e separação, o que não aportaria nenhum progresso ao debate sobre as intenções da prática analítica. Esta oposição, isolada, reconduziria ao modelo binário que Zaltzman (1986/1999) denuncia. Renúncia e conquista entreteriam, juntas, segundo 
a autora, muitas formas de desencontros. A prática analítica consistiria, então, na exploração da complexidade de colaboração das forças mobilizadas. Promoveria a abertura dos recursos das combinações conflituais, em suas ligações, seus desligamentos e alternância de suas funções.

A partir de sua experiência clínica, a autora propõe que o analista, ao escutar e manejar a transferência, não poderia se omitir quanto ao comparecimento de todas as forças atuantes e conflitantes no psiquismo de quem lhe endereça a fala. Ao negar-se a atividade específica das forças de desligamento e impedir que suas formas psíquicas sejam reconhecidas, impede-se que esta atividade pulsional se satisfaça através de representações não psíquicas. Isso ocorreria sempre que, ao preponderar a atividade de Tânatos, fosse concedido, contraditoriamente, privilégio às ligações, às elaborações rumo à sexualidade e aos sintomas dela decorrentes. Zaltzman (1979/1994, 1986/1999) reforça ao longo de seus ensaios que as forças destrutivas, de desligamento, devem ter seu lugar assegurado, pois uma análise assim conduzida liberaria aquilo que, sem saída psíquica possível, poderia, de fato, comprometer a vida do analisando.

De todas as formas de manifestação da pulsão de morte a serem escutadas em análise, a pulsão anarquista seria a que indica a condição de maior precariedade de um paciente. Denuncia haver uma experiência-limite em curso que tornou a sua irrupção necessária, sendo prioritário o trabalho em torno dela. "Analisar um material inconsciente, com predominância anarquista de luta vital contra a morte, no registro libidinal edipiano é um despropósito que apresenta riscos para o destino de um analisando" (ZALTZMAN, 1979/1994, p. 73).

Com o intuito de ilustrar o que abordamos até este ponto do capítulo, no tópico seguinte reuniremos fragmentos e discussões que Zatzman (1979/1994) faz em torno de um tratamento que conduziu. Veremos a psicanalista destacar aquilo que compreendeu serem as manifestações da pulsão de morte e a escuta que elas exigem. Ao mesmo tempo, veremos de que forma ela aponta o equívoco em que incorreria o analista ao analisar um material dessa ordem exclusivamente no registro libidinal. 


\section{3 \\ Um caso clínico}

Ao longo do ensaio “A pulsão anarquista” (ZALTZMAN, 1979/1994), acompanhamos a apresentação de um caso clínico ao qual a autora faz referência para desenvolver seus argumentos com relação à clínica. Afirma a impossibilidade de alcançar efeitos de cura sem que a paciente em questão, Sophia, pudesse dar lugar às representações da pulsão de morte em suas construções ao longo da análise. A busca por tratamento, para ela, se justificava como tentativa de ajudar seu filho, David. A analista identificou, desde o início do trabalho, a existência de uma onipotência recíproca dos laços de afeição entre os dois, o que era motivo de sofrimento para o filho, impedido de viver a seu próprio modo.

O rapaz, acometido de uma leucemia, já havia percebido o quanto aquele laço amoroso "totalitário" estava sendo prejudicial a ele. Já tinha superado uma anorexia e naquele momento vivenciava um adoecimento ainda mais grave. Mais do que amor, a analista supunha estar em jogo uma relação cujo investimento seria, antes de qualquer outra coisa, da ordem de uma necessidade primária. Para além do laço erótico, esse tipo de relação se estabeleceria quando as condições de vida de um ser humano encontram-se em extrema precariedade. David, além de portador dos desejos inconscientes da mãe, funcionaria como seu objeto de necessidade, quase como se satisfizesse uma função vital, o que a conduzia a comportamentos inadequados naquela relação, levando ambos à agonia mental.

Nem a ausência eventual do objeto de amor que alimenta o desejo de viver, nem seu desaparecimento excluem a possibilidade de sobreviver à sua perda. Isto é verdade para toda relação libidinal, mas deixa de sê-lo quando se passa para o registro da necessidade, da necessidade fisiológica, quando, a partir de um certo limiar, a ausência real do objeto da necessidade deixa de ser compatível com a sobrevivência e torna-se ameaça de morte e em seguida causa de morte real. Cada vez que Tânatos ocupa o primeiro plano na cena psíquica, o objeto libidinal se impõe como objeto de necessidade (ZALTZMAN, 1979/1994, p. 47).

A autora não considera que esta força pulsional tenha o poder de criar diretamente uma doença. Mas atribui a ela a apetência, como de qualquer pulsão, por tudo o que favoreça sua descarga, inclusive o adoecimento do corpo. A denegação da atividade da pulsão de morte aumentaria sua pressão interna, a 
fazendo recorrer às vias livres à disposição. Se os recursos psíquicos permanecem barrados, este mecanismo de descarga utilizaria recursos exteriores.

Como única forma possível de se proteger da relação com a mãe, que piorava seu estado e dificultava sua recuperação, a saída encontrada por David foi proibi-la de ir visitá-lo durante o tratamento. A mulher chega à análise em um estado crítico, decorrente da doença do filho e da proibição por ele imposta de se aproximar. Mas, busca a análise com o propósito de aceitar tal imposição, pois suspeitava o quanto aquilo seria salutar para o filho e também para ela.

A separação exigida por David era motivo de intenso sofrimento para Sophia, sobretudo frente aos apelos sociais para que ela transpusesse a barreira instaurada por ele, se submetendo aos ditames do "amor" materno. Este seria o grande desafio da análise, permitir que a pulsão de morte trabalhasse para revogar a denegação da morte, da ruptura, no âmbito psíquico. Essa denegação estaria sendo de fato mortífera e David já buscava, a seu modo, revogá-la, proibindo a mãe de ir vê-lo.

Denegar, conforme nos esclarece Hyppolite (1954/1998) ao comentar o texto freudiano, seria uma forma de suspender o recalque, mas não significa aceitar o conteúdo recalcado. Embora a doença de David e a possibilidade de sua morte fosse uma realidade, sua aceitação, em termos afetivos, não ocorria. O registro intelectual, nos afirma Freud (1925/2011), separa-se do afetivo. Ambos sabiam que a morte era uma realidade possível. Mas, afetivamente, ela permanecia negada. "Nesta recusa se interpenetram a denegação da morte real e a denegação das figuras mentais, das representações psíquicas da pulsão de morte" (ZALTZMAN, 1979/1994, p. 41).

Ao relatar a análise, a autora aponta as formas sutis como esta denegação vai sendo revogada. Num dado momento, a paciente manifesta o desejo de que seu filho saiba o nome de sua doença, o que a analista encara como a instauração de uma luta contra a sua própria recusa da morte (e a consequente perda do filho) e de suas figuras mentais. A partir desse desejo, uma cadeia de pensamentos pode comparecer, permitindo acessar questões familiares que remetiam à mesma dificuldade diante da morte. Esta era a via possível para Sophia, que só reconhecia em si o amor, incluir em suas elaborações os desligamentos necessários à vida. 
A mãe passa a elaborar, em análise, a possibilidade de o filho morrer e as consequências que de tal episódio decorreriam. Imagina que essa morte poderia a liberar de uma antiga inibição de escrever. Se permite pensar que, com a possível morte em jogo, poderia se dispor a buscar alguns documentos de identificação que lhe faltavam. Eram banalidades, consequências desproporcionais à perda em jogo e geradoras de imensa culpa ao serem reconhecidas enquanto pensamentos. No entanto, se mostravam como os únicos caminhos possíveis para a lucidez e o reconhecimento da morte, da separação, da ruptura, até então denegadas. “[...] a análise de Sophia gira em torno do tributo mental a pagar à existência da morte para que a vida aconteça e [...] para que este tributo não precise ser pago na realidade" (ZALTZMAN, 1979/1994, p. 45).

A condução do trabalho, cuja duração, mesmo que por circunstâncias exteriores, tinha sido previamente estabelecida, também seguiu priorizando o respeito a limites. Limites separatórios, limites à presença, instauradores da possibilidade de ausência. Sophia reconheceu, para além de sua angústia, o caráter liberatório, apaziguador do reconhecimento da morte em sua vida. O trabalho analítico permitiu que representações psíquicas substituíssem a materialidade da morte que comparecia asfixiando David como objeto de necessidade.

Zaltzman (1979/1994) questiona se tal análise produziria os efeitos de liberação do amor totalitário observados se fosse conduzida no registro do incesto, priorizando as elaborações em torno da ligação erótica entre mãe e filho. Este foi o modo como havia sido conduzida uma análise anterior à qual Sophia se submetera, alinhada à interpretação edipiana, privilegiando a dimensão libidinal e ignorando os produtos de Tânatos. Resultou, sobretudo, no impedimento da liberação deste laço asfixiante necessária à vida, reforçando a denegação por não considerar a existência da atividade pulsional irredutível às relações libidinais.

A remobilização das forças em jogo teria o efeito de eclodir o assujeitamento recíproco entre mãe e filho. $\mathrm{Na}$ análise anterior de Sophia teria sido levado à risca a domesticação das forças disruptivas pela via libidinal, com o intuito de torná-las inofensivas, “amansá-las”, conforme estabeleceu Freud décadas antes (1924a/2011). 
A domesticação apaziguante pela ligação aos aportes libidinais, para Zaltzman (1979/1994), comporta algo que contenta, sobretudo, alguns analistas e transforma a pulsão de morte em teoria de luxo. Mas o perigo em questão seria o de privar esta categoria pulsional de suas próprias vias de elaboração. $\mathrm{O}$ amor de Sophia pelo filho funcionaria como uma mordaça contra Tânatos e sua ação de desligamento, que só pode irromper tornando o filho David um objeto de necessidade.

A análise de Sophia teria possibilitado a seus pensamentos o desprendimento, a liberação, a inclusão da mortalidade na vida, condição necessária à evolução de sua vida inconsciente. A luta de Sophia consistiu em rever a exclusão de Tânatos da economia psíquica. "Ela se ocupava quase que exclusivamente em permitir que se desenvolvesse o trabalho de desligamento entre ela e seu filho e em desfazer a forma de ligação entre eles, modificando-a” (ZALTZMAN, 1979/1994, p. 73). Assim se encerram os fragmentos do caso, sem dar notícias de desfechos futuros na vida da paciente.

Para que seja possível ao analista conduzir sua prática considerando adequadamente a dimensão da pulsão de morte que Zaltzman (1979/1994, 1986/1999) põe em relevo, a autora faz uma advertência fundamental, que se repete desde Freud: a análise pessoal como imprescindível para o exercício da psicanálise. A mudança da psicanálise enquanto prática não assegura que ela continue a se desenvolver em vigor e fecundidade caso nós, psicanalistas, exponhamos nosso instrumento de trabalho principal, nossa própria psique, a fenômenos de proteção e usura na forma de resistência à análise. Resistência que, conforme veremos a seguir, Freud (1937/2018, 1940 [1938]a/2018, 1940 [1938]b/2018) considera um dos maiores obstáculos à cura e a partir da qual Zaltzman (1996) se propõe a encontrar saídas mais otimistas no legado freudiano.

\section{4}

\section{Adoecimento e cura em psicanálise}

Ao questionar a prioridade ou mesmo a exclusividade atribuída à dimensão sexual no adoecimento psíquico e, por consequência, no tratamento analítico, 
Zaltzman se preocupou em conceber, a partir da obra de Freud, perspectivas mais adequadas ao manejo dos efeitos da pulsão de morte no psiquismo. Não apenas da pulsão de morte, mas de todo o espectro de novas dificuldades apresentadas pela clínica. Para isso, sugere extrairmos as consequências do legado freudiano nos chamados textos antropológicos. Em "Le normal, la maladie et l'universel humain", Zaltzman (1996) supõe que esta parte da metapsicologia contém indicações para uma melhor concepção das ambições terapêuticas da análise. Daí a ideia de cura e de doença psíquica poderem se esclarecer e a prática se orientar.

Para levar a cabo sua proposta, Zaltzman (1996) retorna, primeiramente, à questão: “o que é a cura psicanalítica tal qual comparece após as diversas revisões feitas por Freud em seus trabalhos testamentários?” (ZALTZMAN, 1996, p. 1124). A intenção da autora ao se referir a tais "revisões" é a mesma que abordamos no primeiro tópico, ou seja, demonstrar que, ao revisar suas propostas iniciais, Freud traz novidades muitas vezes desconsideradas pelos analistas. A pista que Zaltzman nos dá para responder à questão colocada é acompanharmos Freud em seus últimos trabalhos. Neles encontramos a afirmação de que o interesse dos analistas na cura através da psicanálise não estaria corretamente dirigido e "em vez de perguntar como a cura se dá pela análise, deveriam perguntar que obstáculos se põem no caminho" (FREUD, 1937/2018, p. 282).

Seguindo as indicações da psicanalista, vamos às obras testamentárias do autor, onde ele, revelando o realismo contido em sua paixão pela psicanálise, põe em questão seu poder de cura, nos remetendo às resistências ao tratamento. As reflexões freudianas se encerram indicando as adversidades à cura com as quais ele se deparou ao longo de sua trajetória. "A superação das resistências é a parte do nosso trabalho que exige mais tempo e maior esforço. Mas ela vale a pena, pois realiza uma vantajosa alteração do Eu [...] e se mostrará válida por toda a vida" (FREUD, 1940 [1938]a).

Em “Análise terminável e interminável” (FREUD, 1937/2018), revela que em uma análise, tanto de homens quanto de mulheres, o analista se depara com a recusa do feminino. Na mulher, a inveja do pênis, a aspiração de possuir um genital masculino. No homem, a revolta contra a atitude passiva. Ao avançar sobre a bissexualidade e a angústia de castração, a análise reencontraria a resistência última 
no rochedo da rejeição da feminilidade, o que caracterizaria a psique humana desde o início de sua constituição.

No caso dos homens, não haveria perigo maior para a função heterossexual do que ser perturbado por uma homossexualidade latente. Mas o fato de correntes rivais não dividirem entre si o montante de libido exigiria, para Freud, uma explicação específica: a tendência ao conflito. "Temos a impressão de que a tendência ao conflito é algo específico, novo, que vem se juntar à situação, independentemente da quantidade de libido" (FREUD, 1937/2018, p. 313). E tal tendência estaria relacionada à intervenção de uma parcela de agressividade livre. Ao supor o reconhecimento de tais casos como expressão da pulsão de destruição, Freud questiona: "não seria possível estender essa concepção a outros tipos de conflito, não deveríamos até mesmo revisar tudo o que sabemos sobre o conflito psíquico segundo essa nova perspectiva?" (FREUD, 1937/2018, p. 313).

Com o "Compêndio de psicanálise" (FREUD, 1940 [1938]a/2018), onde ele recapitula as aquisições da análise, nomeia dois novos obstáculos: um deles é a necessidade de estar doente, que remete ao sentimento de culpa inconsciente que exige a infelicidade, porção da pulsão de morte "amarrada" pelo Supereu. O outro é a pulsão de morte ao retornar para o próprio sujeito em forma de destruição ou agressão. Assim Freud se expressa:

Mais difícil é demonstrar que há outra resistência, para a qual nossos meios de combate são muito insatisfatórios. Entre os neuróticos existem pessoas em que, a julgar por todas as reações, o instinto de autoconservação foi praticamente revirado. Elas parecem ter como objetivo apenas prejudicar e destruir a si mesmas. Talvez pertençam a este grupo os indivíduos que afinal cometem suicídio realmente. Supomos que neles tenham acontecido extensas disjunções de instintos, em virtude das quais foram liberadas imensas quantidades de instinto de destruição voltado para dentro. Tais pacientes não suportam a ideia de recuperação pelo nosso tratamento, opõem-se a ela de toda maneira. Mas admitimos que esse é um caso que ainda não pudemos esclarecer totalmente (FREUD, 1940 [1938]a/2018, p. 237).

O autor já apontava em "O Problema econômico do masoquismo" (FREUD, 1924b/2011, p. 292): “Qual a importância das pulsões de morte que escapam a este domínio adquirido pela ligação aos aportes libidinais, nós não podemos adivinhar atualmente". A culpa inconsciente, o gosto pela infelicidade e a autodestruição se opunham à cura definida como possível através de um processo analítico. 
Em “A cisão do Eu no processo de defesa” (FREUD, 1940 [1938]b/2018), ele formula a falha daquilo que seria o último aliado no processo de cura analítica. Ainda jovem, o Eu, ao buscar uma saída diante de um conflito real entre uma exigência pulsional e a objeção da realidade, opta pelas duas saídas. Prossegue com a satisfação e ao mesmo tempo rejeita a realidade. Mas o preço a se pagar por tal solução é uma fissura do Eu que não curará jamais. "As duas reações opostas ao conflito prosseguem como núcleo de uma cisão do Eu" (FREUD, 1940 [1938]b/2018, p. 347) e sua função de síntese fica sujeita a uma série de distúrbios.

Por se deparar constantemente com desafios e novos obstáculos desde seu surgimento, a psicanálise necessita dispor do corpo metapsicológico, o qual seria capaz de acolher as novidades e abrir novas via terapêuticas, conforme vimos no início do primeiro capítulo. Assim, uma configuração patológica particular se insere nos tratados gerais do funcionamento do psiquismo. Freud (1937a/2018, p. 287) nos dizia ser preciso chamar a "bruxa metapsicológica" para cumprir os objetivos terapêuticos, o "amansamento" pulsional e sua integração na harmonia do Eu.

Zaltzman (1996) chama a atenção para o fato de o sujeito freudiano ser, potencialmente, um doente polimorfo e a alternativa ao polimorfismo mórbido não seria a normalidade. De modo similar, a alternativa de Freud (1905/2016) à perversão polimorfa ligada ao anacronismo libidinal não foi a normalidade. A metapsicologia seria, assim, o que possibilita a investigação de saídas para as adoecedoras formações de compromisso entre duas grandes vertentes do psiquismo: a lógica do inconsciente e a perspectiva da razão e da realidade.

Ao mesmo tempo que destaca a importância da pulsão de morte para o vigor da clínica psicanalítica, a autora propõe ampliarmos o olhar acerca da obra freudiana, nos remetendo à necessidade de ver que Freud, até seus últimos trabalhos, esteve ocupado em revelar novas dificuldades impostas ao tratamento analítico. Não apenas a pulsão de morte, mas tudo que se revelava fonte de resistência ao tratamento como a bissexualidade, a recusa ao feminino, a cisão do Eu. Este conjunto de fatores passa a ocupar lugar nas configurações do psiquismo, ascendendo ao estatuto de tratados gerais, participando da constituição de todo sujeito. 
É preciso considerarmos que, sobretudo na sua trajetória final, o fundador do método psicanalítico se mostrava fundamentalmente pessimista, devendo ser situado, conforme observou Lacan (1956/1988), numa tradição realista e trágica, negando qualquer tendência ao progresso. Fortes (2012) aponta que, com a pulsão de morte, Freud não indicou apenas a força da repetição, mas positivou a morte, mostrando que a vida não nos leva necessariamente a uma evolução.

Mas Zaltzman (1996) questiona: se a psicanálise desvela a condição de inevitável desequilíbrio do homem, ela poderia distinguir o sujeito que porta uma existência "normal" daqueles que encontram apenas soluções mórbidas na vida psíquica? O que seria, então, a doença no senso psicanalítico?

Seguindo Freud, a autora considera ser o adoecimento psíquico a experimentação de um sofrimento impotente, resultado da substituição de uma prova real de perigo por um sofrimento fictício. Tal sofrimento decorre da luta do Eu contra o sintoma, substituto e derivado do impulso recalcado, que continua a desempenhar seu papel, renovando a exigência de satisfação. Obriga, então, o Eu a emitir constantemente o sinal de desprazer e se dispor para a defesa (FREUD, 1926/2014). O sinal de desprazer é o que Freud (1917/2014; 1933b/2010) aborda como sendo a angústia neurótica, estado afetivo resultante da união de sensações com inervações de descargas a elas correspondentes e sua percepção.

Apesar de insistirem, as vozes da morte e do incesto não poderiam vencer o golpe do interdito, só podendo comparecer por vias indiretas. Mas seu cumprimento de forma direta seria, do ponto de vista dos interesses globais do psiquismo, ainda mais comprometedor. A saída possível seria o remanejamento das forças pulsionais, atestando a transposição da impotência em ganho de "Eu". Para isso, seria necessário o afrouxamento das resistências no curso do processo analítico. A cura em psicanálise seria o efeito, a consequência da efetuação do processo de análise, onde somente a suspensão das resistências possui um poder terapêutico (ZALTZMAN, 1996).

Em vários momentos dos ensaios freudianos localizamos essa "saída", via remanejamento pulsional, de forma bem clara. $\mathrm{Na} 31^{\mathrm{a}}$ das Novas Conferências Introdutórias, Freud (1933a/2010, p. 223) indica que a intenção da análise é “fortalecer o Eu, torná-lo mais independente do Supereu, ampliar seu âmbito de 
percepção e melhorar sua organização, de maneira que possa apropriar-se de novas parcelas do Id”. Já em “Análise terminável e interminável” (FREUD, 1937a/2018) esclarece-se que a análise faz com que o $\mathrm{Eu}$, amadurecido e reforçado, empreenda revisões de antigos recalques, destruindo alguns e reconstruindo outros de maneira mais fortalecida e sólida, de modo que possam suportar acréscimos pulsionais. Com isso, "a verdadeira realização da terapia analítica seria a correção a posteriori do processo de repressão original, correção que dá fim à preponderância do fator quantitativo" (FREUD 1937a/2018, p. 290).

É importante diferenciarmos este trabalho com qualquer tipo de "adestramento" do Eu, desvio do trabalho analítico denunciado por Lacan (1958/1998, p. 591), que seria um empenho na "reeducação emocional do paciente". O autor cita como exemplo a tradução da expressão "Wo es war, soll Ich werden", feita por uma sociedade psicanalítica, para o que seria, em francês, "O Eu deve desalojar o Id", remetendo a uma exclusão da parte "ruim" do funcionamento psíquico. Tal sentido diverge totalmente de "Onde era Id, há de ser Eu" (FREUD, 1933/2010, p. 223) que remeteria a uma apropriação de novas parcelas do Id.

No tipo de terapia condenada por Lacan, o analista guiaria o analisando em direção à "happiness" - referência ao modelo norte-americano - se colocando como sujeito na relação, elegendo o que é bom e o que não é para o paciente, dirigindo sua vida e não o tratamento. $\mathrm{O}$ autor adverte que o único lugar do analista e seus sentimentos durante o processo analítico é o de morto. Neste sentido, é importante considerar que, ao lidar com as resistências e fazer uma interpretação, essa é recebida pelo paciente como proveniente da pessoa que a transferência imputa ao analista, não podendo ele ocupar este lugar, que consiste em um lugar de poder. A interpretação não pode ser uma exigência da fraqueza do paciente à qual é preciso acudir. Isso refletiria as paixões do analista, seu medo da ignorância, sua necessidade de estar por cima, seu medo de decepcionar. Estas são consequências de uma relação dual, caso o analista não a supere (LACAN, 1958/1998).

Para compreendermos como isso é possível, devemos ter em vista o fato da ocorrência da transferência durante a análise, situação em que o analisando enxerga no analista a "reencarnação" de alguém importante de seu passado e, por isso, transfere a ele sentimentos e reações que se refeririam àquele modelo. Ao mesmo 
tempo que funciona como um instrumento valioso, seria fonte de sérios perigos. Dentre eles, a tentação que o analista corre de tornar-se mestre, modelo e ideal para outras pessoas, criando indivíduos segundo a sua imagem, o que o tornaria infiel à sua tarefa (FREUD, 1940 [1938]a).

Nesta mesma perspectiva, Zaltzman (1999), em "La dictadure de la guerison", aponta que o tratamento analítico, na medida em que não visa doutrinar o sujeito, mas permitir que disponha dos recursos que nele já se encontram, não pode pretender, também, fazê-lo adquirir independência, autossuficiência e tranquilidade narcísica. A autora adverte que analista e analisando devem estar livres da miragem de um psiquismo que visa à conquista de um "Eu identidade", fechado em si mesmo, o que seria, para ela, uma "ditadura da cura".

Este trabalho de transposição, de ganho de Eu, que Zaltzman (1996) revisita na obra de Freud, seria o caminho possível para empreender a tarefa de fazer frente a uma visão desanimadora dos resultados de uma análise. A autora propõe considerarmos a realização de tal trabalho a partir de algumas hipóteses encontradas nos ensaios antropológicos freudianos. Neste percurso, demonstra apostar cada vez mais na dimensão coletiva do psiquismo, postura notadamente influenciada pela leitura dos ensaios sociais freudianos. Para Zaltzman, é na última obra de Freud, “Moisés e o monoteísmo" (1939 [1934-1938]/2018), que podemos identificar um "além da doença", contexto no qual se inclui a possibilidade da cura através da análise.

\section{5 \\ Transgredir por pertencer: o coletivo no contexto da clínica}

Apostar na transgressão como saída psíquica vital só seria possível, conforme nos indica o pensamento de Zaltzman, ao considerarmos a condição humana de pertencimento à espécie. A garantia de haver, em última instância, uma ligação ao conjunto humano que se sobrepõe a todas as ligações de "um" a "um" asseguraria a cada sujeito a possibilidade de compartilhar suas experiências com o grupo, se apropriando do patrimônio simbólico universal, o que primordialmente seria pura pulsão. 
Em reforço a esta ideia, encontramos no ensaio "La dictature de la guerison" (ZALTZMAN, 1999) a descrição de um aparelho psíquico que não se enquadra em um modelo de circuito fechado em si mesmo, nos moldes de um autofuncionamento. A autora propõe pensarmos em um modelo de aparato, no qual o humano é habitado por diversos outros, de passagem ou instalados em seu psiquismo, todos herdeiros da grande história coletiva.

O aparelho psíquico apresentado na segunda tópica freudiana já contemplava uma dimensão representante dos modos de regulação coletivos (WINOGRAD, 2012) na figura do Supereu, não se constituindo, por isso, em um circuito fechado. Mas a proposta de aparelho que Zaltzman (1999) nos apresenta como objeto de intervenção na clínica difere no sentido de se constituir como um minúsculo fragmento de um aparelho do organismo vivo maior, constituído pelo conjunto humano e sua história. Por consequência, a orientação interpretativa seria totalmente diferente daquela que considera o aparelho como unidade apartada do todo.

A psicanalista reforça, por esta via, ser indispensável considerarmos o que Freud (1915b/1987) estabeleceu em sua hipótese da filogenia. Embora cada sujeito esteja limitado no espaço-tempo de sua existência biológica, o psiquismo participa de um modo de vida imortal no polo das pulsões e no polo da história cultural da espécie humana. Esta inevitável participação que se inicia com a prematuração e completa dependência de um outro, não obedece somente às necessidades vitais. Os interesses comuns se impõem, estabelecem e mantém o domínio de uma coesão interna sobre os interesses individualistas que divergem um sujeito ou grupo de sujeitos da unidade maior da humanidade. O conteúdo inconsciente seria, neste sentido, coletivo, propriedade da espécie humana e constituiria o patrimônio universal, herança determinante que acolhe cada infans que nasce.

Desde então, o espírito humano buscaria sentido, objetivo, direção, transformando em plano de vida coletiva o princípio do prazer. Mas o que se constata é que nenhuma área desenvolvida pelo homem, da religião à ética, foi capaz de oferecer uma alternativa ao adoecimento, permanecendo o conflito entre a vida pulsional e as resistências que se impõem contra ela. Como técnica, a psicanálise teria a oferecer satisfações substitutivas ao adoecimento. $\mathrm{O}$ tratamento 
analítico se colocaria como uma via de desvio, transgredindo imposições adoecedoras e ofertando um caminho novo à doença. Deste modo, a energia imobilizada em uma renúncia impossível, um recalque intransponível pode, pela via transferencial, estabelecer um movimento centrífugo (ZALTZMAN, 1999), em direção ao coletivo. É em direção ao coletivo que se poderia reaver, através da análise da transferência, o curso possível de uma evolução psíquica.

Em outras palavras, a alternativa possível à propensão humana ao sofrimento, a disposição à saúde psíquica se sobrepondo ao adoecimento só seria possível, a partir dessa leitura, no terreno da psicologia coletiva. A evolução individual estaria ligada à cena do ser psíquico coletivo.

Para compreendermos os fundamentos de tal perspectiva a partir do texto freudiano, será necessário nos aproximarmos sobremaneira do ensaio testamentário "Moisés e o monoteísmo" (FREUD, 1939 [1934-1938]/2018). Acompanhar a proposta resgatada desse texto exige que retornemos a ele, o que poderá suscitar uma digressão em nossa exposição nos parágrafos seguintes. Mas tal manobra se justifica pois possibilitará delimitarmos os argumentos da narrativa freudiana que sustentam a articulação de Zaltzman da qual nos ocuparemos em seguida.

Tendo sido recortada e esclarecida, no texto de Freud, a ideia que orienta a proposta da autora de que as manifestações decorrentes da pulsão de morte poderiam ser acolhidas na clínica, estará justificada nossa estratégia. A pretensão é que, ao final deste tópico, esteja clara a ideia de que só é possível pensarmos em uma "transgressão" na clínica, com o acolhimento do material simbólico oriundo da ação de Tânatos, em recusa ao privilégio de Eros, em virtude da condição de pertencimento do humano ao coletivo. Explicita-se, deste modo, na obra de Freud, a junção entre metapsicologia, clínica e cultura, sendo impossível pensar em cura psicanalítica fora dessa conjuntura.

Ao retornarmos, orientados pelos apontamentos de Zaltzman, a "Moisés e o monoteísmo" (FREUD, 1939 [1934-1938]/2018), longo e denso ensaio que Freud escreve já encerrando seus trabalhos e na iminência da Segunda Guerra Mundial, conseguimos compreender o otimismo que a autora, paradoxalmente, extrai das palavras do fundador da metapsicologia, quando sua crença no método analítico e no progresso da humanidade já se mostrava bastante abalada. O ensaio se apresenta 
como tentativa de explicar a origem do caráter especial que o povo judeu se auto atribui. Expõe, inicialmente, que Moisés, líder daquele povo, teria forjado seu caráter ao dar-lhe uma religião que aumentou tanto sua autoestima que o fez se julgar superior aos outros povos. Após isso, mesmo tendo seus integrantes sido afastados entre si, manteve-se unido, independente de fatores sanguíneos - uma das hipóteses de Freud era, inclusive, que Moisés era egípcio - pois o que mantinha essa união em um fator ideal era a posse em comum de uma riqueza intelectual e emocional.

Isso teria sido possível pois Moisés permitiu ao seu povo participar da grandiosidade de uma nova ideia de Deus, ao afirmar que aquele era o povo escolhido por Ele, impondo um avanço em intelectualidade que lhe abriu caminho à apreciação do trabalho racional e a renúncias pulsionais. No entanto, para Freud, haveria uma motivação mais profunda para este povo perceber-se especial, afinal a religião de Moisés foi rejeitada e esquecida por dois longos períodos históricos, só irrompendo posteriormente pela via da tradição.

Para compreender como tal processo ocorreu é importante, conforme o próprio Freud orienta, um retorno à sua obra anterior "Totem e tabu" (FREUD, 1912-13/2012). Naquele ensaio, ele aproxima a evolução individual à evolução da massa humana e sua ambivalência de sentimentos com relação ao pai. Tomando de empréstimo a hipótese de Darwin, Freud supõe que os seres humanos viviam originalmente em pequenas hordas, governadas, cada uma delas, por um macho despótico mais velho que se apropriava de todas as fêmeas e castigava ou se livrava dos machos mais novos, inclusive os seus filhos.

Tal sistema termina com uma rebelião por parte dos filhos, que se reúnem em bando contra o pai, o matam e devoram. A vida em paz entre eles exigiu a renúncia às mulheres, origem da morte do pai, e a instituição da exogamia. A atitude emocional ambivalente dos filhos com relação ao pai teria permanecido no desenvolvimento posterior, sendo investida em um animal totêmico colocado no lugar dele. $\mathrm{O}$ animal, adorado por todos, era devorado em uma cerimônia como repetição da morte do patriarca, a qual estabeleceu a ordem social, as leis e a religião. 
O que Freud (1912-3/2012) pretende ao retomar esta suposição mítica é aproximar a evolução de um povo ao desenvolvimento do indivíduo, afirmando que aquilo que foi reprimido no passado retorna, por meio da tradição, assim como na vida mental de cada um de nós. Mas o retorno do recalcado se efetua lentamente e sob influência das mudanças nas condições da história da civilização. O pai voltou a ser o chefe da família, mas não tão irrestrito como o pai da horda primeva. Sua magnificência foi restaurada e os afetos a ele relacionados puderam se repetir.

Em um ensaio posterior, vemos reforçada a ideia do retorno de uma figura paterna não tão inacessível como o pai da horda. "Neurose de transferência: uma síntese" (FREUD (1915b/1987) propõe a hipótese da filogênese. Supõe uma sequência de momentos históricos pelas quais a espécie humana teria passado do começo ao fim dos tempos glaciais e aos quais os psiconeuróticos regrediriam em função de uma predisposição herdada da vivência das auguras daqueles tempos.

O ponto que mais nos interessa agora, deste recém descoberto manuscrito, está na descrição final do ciclo histórico apontado, quando novamente Freud (1915b/1987) propõe que a sociedade teria se dividido em hordas isoladas dominadas por um homem sábio, forte e brutal como pai. Mas neste ensaio o autor indica algo a mais. Propõe que, talvez, a natureza desconsiderada, ciumenta e egoísta atribuída ao pai primitivo da horda não existisse desde o começo, surgindo como adaptações às necessidades impostas pelo percurso dos tempos glaciais. E do mesmo modo como o pai inacessível e egoísta sucumbiu à violência das relações familiares que ele próprio criou e retornou depois como divindade, também esse outro tipo paterno teria sucumbido diante das exigências da vida sexual, mas retorna posteriormente, sendo "o mais valioso para o desenvolvimento da cultura" (FREUD, 1915b/1987, p. 78).

A ambivalência estaria, deste modo, na essência da relação com o pai. Mas, já retornando ao ensaio sobre Moisés, vemos que sua religião conhece apenas os sentimentos positivos para com o Deus-pai. Não havia lugar, na estrutura da religião mosaica, para uma expressão de ódio com relação ao pai, surgindo, em seu lugar, uma reação contra esse ódio em forma de sentimento de culpa, aumento do ascetismo moral e renúncia pulsional (FREUD, 1939 [1934-1938]/2018). 
Mas a influência mais decisiva dessa mudança interior estaria relacionada a uma representação nova da ligação e do bem comum entre os homens, o que Zaltzman (2007) chama, inspirada em Freud, de exercício do espírito. A força do espírito estaria no investimento do poder intelectual, na superioridade que lhe é reconhecida com relação ao poder das sensações e da sensualidade na decifração dos enigmas da vida de cada um, mas também da condição humana e de sua origem, o que teria sido incentivado por Moisés.

O avanço na espiritualidade equivale a se decidir contra a percepção sensorial direta, em favor dos assim chamados processos intelectuais superiores, ou seja, lembranças, reflexões, inferências; [...] A rejeição de uma exigência instintual sexual ou agressiva parece ser algo muito diferente. [...] Assim, vemo-nos ante o fenômeno de que, no desenvolvimento da humanidade, a "sensorialidade" foi gradualmente sobrepujada pela intelectualidade e os seres humanos se sentiram orgulhosos e elevados por cada um desses avanços (FREUD, 1939 [1934-1938]/2018, p. 163).

Com o surgimento da figura do homem Moisés, o que se confirma é a mudança gradual a qual Freud alega ter ocorrido ao longo da história. Não foi Moisés que, magicamente, "inaugurou” um novo ciclo histórico para a humanidade. Ele também seria produto da repetição, via tradição, de uma mudança ocorrida ao longo da filogênese, da qual "não sabemos dizer porque devia ser assim" (FREUD, 1939 [1934-1938]/2018, p. 163). Tanto é que o próprio surgimento do patriarcado, que Freud considera um dos avanços da intelectualidade, não teve origem com a imposição de um "pai", pois somente o avanço teria o elevado à condição de autoridade.

A ligação entre os homens teria advindo filogeneticamente de um sentimento comum com relação ao pai, permitido pelo avanço da intelectualidade. Ao se reconhecer como iguais, os homens puderam manifestar, pelas vias simbólicas coletivas, os impulsos sexuais e agressivos, destruidores. O poder intelectual e sua superioridade com relação às sensações seria o fundamento do trabalho de transposição do pulsional para formas enunciáveis, compartilháveis, compondo o Eu e o grupo.

A herança primitiva teria dado, assim, origem a tais comportamentos, sendo esta a explicação de Freud para o comportamento e o modo especial de se perceber dos judeus, que acabou por se espalhar entre os povos. 
Ao revisitar este ensaio, Zaltzman (1996) aponta que, retroativamente a ele, todas as obras de Freud consagram a dimensão filogenética do inconsciente desenhando a existência de um pacto entre os homens que amarra a integridade narcísica de cada um à evolução narcísica impessoal do conjunto.

Freud nos mostraria assim que, fazendo advir uma figura paternal diferente do pai genital da horda e para além de sua morte, Moisés é aquele que atualiza a aliança dos homens entre si. Zaltzman (1996) entende que esta obra final, originada de todas aquelas que a precedem, revela uma nova relação possível entre homens. Esta se constituiria por uma referência comum cumprida pelo conjunto humano sob pressão de um movimento libidinal de fundo, de um impulso erótico interno instaurando em sua história a figura do homem Moisés.

A característica capital dada à referência paternal participa das vias pelas quais se constrói a elaboração inconsciente de um ponto de ancoragem, fundador e garantia de integridade psíquica de cada um de nós: um ponto de certeza de seu pertencimento à espécie humana. Além disso, a convicção daquilo que ele deve fazer a si mesmo e aos outros, formando uma ligação confiável entre cada ser humano e sua comunidade a outros humanos, o que o permite não "tombar fora do mundo" (ZALTZMAN, 1996, p. 84).

Em alguns momentos, o texto da autora chega a suscitar a impressão de que, por fim, chegamos à solução que ela tanto combate, com o triunfo salvador de Eros sobre a pulsão de morte. Mas a identificação à espécie humana é de outra ordem, não se reduzindo à ligação a um objeto específico. Ela é direta, imediata, anterior a qualquer ligação determinada. Freud (1939 [1934-1938]/2018, p. 162) também aponta essa forma de ligação ao dizer que "não se trata de uma renúncia instintual e não há uma segunda pessoa ou instância pela qual se faz o sacrifício".

Seria, para Zaltzman (1996) a mesma identificação que resta aos sobreviventes, que permite resistir frente às tentativas de imposição da morte individual ou coletiva, conforme reportada na literatura concentracionária. Testemunha a existência de uma referência inconsciente de inclusão indestrutível no devir humano, conforme Antelme (1957/2013) propôs ao refletir sobre a insistência dos concentracionários em viver, a despeito da destruição brutalmente imposta. Neste sentido, a perspectiva anunciada de modo algum retira as 
prerrogativas da atuação de Tânatos defendidas por Zaltzman, ao contrário, é o que as impulsiona.

A ideia retomada por Zaltzman (1996) é a de que todos nós levamos uma dupla existência: tanto somos nosso próprio fim, quanto somos parte de uma corrente à qual estamos assujeitados, mesmo que contra nossa vontade, ou ao menos sem intervenção dela. A distinção das pulsões sexuais e das pulsões de morte refletiria, assim, esta nossa dupla função. A esta dupla função, nosso destino pessoal e nosso destino comum, não poderíamos nos subtrair. Cada vida individual representa a ela própria e recapitula o universo humano em seu inteiro: na sua evolução, seus avanços e regressões. E este universo, no seu conjunto, teria parte ligada ao destino de cada humano que o compõe.

Através do homem Moisés, teria se inscrito na história do pensamento humano uma saída psíquica para além da repetição da morte primitiva. É esta saída que a autora aponta ter Freud evocado em termos de progresso do espírito, abrindo a via para um além da culpabilidade inconsciente que exige uma dose contínua de sofrimento mórbido e estéril. "À doença humana, a cura analítica aporta a perspectiva de um progresso do espírito. O salutar do mórbido é uma saúde do espírito" (ZALTZMAN, 1996, p. 1131, tradução nossa).

A autora reconhece que alguns termos do pensamento lacaniano nutrem o enigma pelo qual o Moisés de Freud coroa sua obra metapsicológica e sua própria ideia de homem. Lacan e seus sucessores assinam o registro simbólico, o Nomedo-Pai como função chave e de palavra mestre decisiva. Para o psicanalista francês, a última palavra da antropologia freudiana interroga sobre o que possui o homem e faz dele suporte de uma razão da qual é mais vítima do que senhor, estando por ela condenado. O homem, nos diz Lacan (1956/1988), é possuído pelo discurso da lei, com o qual se castiga em nome da dívida simbólica que não cessa de pagar em sua neurose. "Na perspectiva freudiana, o homem é o sujeito preso e torturado pela linguagem" (LACAN, 1956/1988, p. 276).

Por outro lado, a linguagem seria a via que instaura uma identificação simbólica coletiva consecutiva à morte e permite a transposição do pulsional em capital simbólico compartilhável. Esta condição de pertencimento e ligação comum é apontada por Zaltzman (2007) como o recurso que possibilita vislumbrarmos 
resultados mais otimistas para a prática analítica e para convivência social frente aos obstáculos que Freud apontou, sobretudo com relação à existência da pulsão de morte.

Neste sentido é que consideramos haver uma entonação transgressiva nas considerações de Zaltzman acerca da clínica. Ela recorre ao texto que, praticamente, encerra o legado freudiano para propor uma revisão em toda metapsicologia que o antecede. Ilumina, nas palavras de Freud, a existência, ao lado da renúncia pulsional e do ascetismo moral, de um pacto entre os homens constituído na dimensão simbólica. Este pacto asseguraria a cada um a possibilidade de transpor em linguagem compartilhável toda sorte de manifestação pulsional. Ao se apropriar dessa condição humana de pertencimento, a clínica psicanalítica permitiria a cada sujeito em análise movimentar as forças pulsionais em direção aos "processos intelectuais superiores" (FREUD, 1939 [1934-1938]/2018, p. 163), o que incluiria as manifestações da pulsão de morte, que Freud considera como pulsão agressiva. A transgressão seria justamente a proposta de acolhimento das manifestações de Tânatos no processo de análise, não subordinando seus efeitos aos desígnios de Eros, tampouco negando sua existência.

O pertencimento seria, segundo Guarnieri (2011), "le fil rouge" que liga o pensamento de Zaltzman em um movimento que, seguindo o percurso freudiano, mantém uma forte coerência e se encerra com a leitura que a autora propõe para o termo "trabalho de cultura". Este, que abordaremos no próximo capítulo, estende a concepção ligada à cura em psicanálise para o âmbito do progresso pretendido pela humanidade. Tratar-se-ia da composição de um pensamento que endossa plenamente a pulsão de morte no psiquismo individual e na cultura humana, revelando a vitalidade da transgressão frente a movimentos que negam ou impedem tal força de se manifestar psiquicamente, fomentando sua irrupção por vias materiais e violentas.

Chegamos, com Zaltzman (1996), à seguinte conclusão: quanto à análise, cada cura acompanha-se do fato da natureza inseparável do individual ao coletivo. A psicanalista encerra seu artigo de 1996 com a evocação de duas vias possíveis de ancoragem narcísica coletiva como alternativa ao adoecimento. 
A primeira delas é esta que se inicia com a atitude do pensamento científico de Freud e que levamos a frente em nossa atividade cotidiana. É a insistência, a despeito dos obscurantismos do pensamento ilusório e das falsificações da realidade para as formações mórbidas, em transformar a experiência subjetiva de cada vida individual em um conhecimento comum, capital compartilhável. A realidade e a razão têm, no exercício psicanalítico, um estatuto distinto daquele que lhe confere o pensamento religioso, por exemplo. Mesmo entre os psicanalistas é possível constatarmos posturas ilusórias, de evitamento quanto a determinadas dimensões do humano.

Nessa direção, é preciso afirmarmos que a cura psicanalítica deve se dispor ao reconhecimento deve estar aberta a Tânatos tanto quanto a Eros. Desde seu primeiro trabalho, Zaltzman (1979/1994) apontava essa dimensão da análise: "Onde impera a pulsão de morte (...) a análise deveria sustentar este trabalho de liberação, ao invés de dissimulá-lo em novas associações" (ZALTZMAN, 1979/1994, p.74). É isto que cumpre a transformação. Como o sentimento de pertencimento à espécie humana, a razão e a realidade são conquistas do espírito, individual e coletivo.

A outra via é a que observamos em trabalhos como os de autores que se dedicam à literatura concentracionária, ou de testemunho. Por ela, seria possível transformar uma experiência traumática bruta - individual e coletiva - em obra interpretativa comum. Assim como a literatura concentracionária, cada análise transformaria o conflito mais singular e, no entanto, comum a todos, em via interpretativa para o grupo. Desse modo, Zaltzman (1996) considera impossível evocar a validade do tratamento pela análise fora desta dimensão múltipla de cada psiquismo. A dimensão coletiva do psiquismo recebe cada vez mais atenção e importância na medida em que os ensaios de Zaltzman avançam. Do mesmo modo, observamos crescer seu interesse pelo quinhão maléfico e destruidor do humano e a busca de alternativas frente a severos oponentes à harmonia da convivência entre os homens.

Por isso, no último capítulo de nossa pesquisa acompanharemos Zaltzman (2007) desenvolver a temática do mal, relativa a uma dimensão inerente à constituição psíquica. $\mathrm{O}$ mal, sob esse viés, poderia ser definido como ação que 
causa dor e sofrimento a um indivíduo, a um grupo ou mesmo ao futuro da humanidade. Ele comparece como uma possível forma de manifestação da pulsão de morte, mesmo que não obrigatoriamente, ao ser apreendido do ponto de vista da metapsicologia.

Como via proposta para a apreensão da dimensão do mal, veremos a autora apresentar uma leitura específica, nos ensaios freudianos (FREUD, 1933a/2010), da definição de "trabalho de cultura". Com isso, Zaltzman nos remete novamente à ideia de pertencimento, mas desta vez preocupada com questões que ultrapassam o limite da clínica psicanalítica, aportando dificuldades que a humanidade enfrenta ao buscar o progresso civilizatório.

Veremos sua insistência em apontar, a partir da leitura psicanalítica, possibilidades no enfrentamento da barbárie que nos acomete de modo recorrente. Ao mesmo tempo, há uma apreciação sobre a perenidade do mal latente que a humanidade carrega, só esperando condições propícias para se manifestar. Isso já aponta para os limites aos quais as "saídas" iluminadas por Zaltzman na obra freudiana, tanto na clínica quanto no processo cultural, estão submetidas, confirmando a insistência de um "resto incurável", que será analisado a partir da abordagem desta enigmática vertente do funcionamento psíquico: o mal. 


\section{4}

\section{A via transgressiva do processo civilizatório}

No percurso que empreendemos ao longo dos capítulos anteriores, buscamos revelar como os escritos de Zaltzman aportam um julgamento positivo da transgressão ao abordá-la a partir de articulações que poderíamos agrupar em dois eixos temáticos: a metapsicologia e a clínica. Quanto às contribuições à metapsicologia, tratamos do aspecto transgressivo relativo ao operador conceitual "pulsão de morte”. Enquanto força, essa pulsão se voltaria contra suas próprias correntes destrutivas, em um movimento anárquico que garantiria ao psiquismo não ser aniquilado quando submetido a circunstâncias exacerbantes e adversas como, por exemplo, o totalitarismo de um outro ou de poderes maiores. Seria a expressão maior da subversão psíquica, que irrompe quando a vida dá sinais de esgotamento.

Em relação à clínica, também conduzimos nossa abordagem a partir de seu aspecto violador. A ruptura, neste caso, estaria direcionada ao comprometimento com uma prática que direcione o olhar tão somente ao trabalho de Eros e aos conflitos decorrentes dos investimentos libidinais. Procuramos demonstrar como as manifestações da pulsão de morte devem ser reconhecidas em um processo de análise. Seu mecanismo de desligamento, as rupturas dele derivadas, seriam cruciais ao trabalho de cura, o que ilustramos com um caso clínico apresentado por Zaltzman (1979/1994).

Finalizando o segundo capítulo, estreitamos a investigação em torno dos fundamentos encontrados pela autora, na obra freudiana, que justificam a possibilidade e a urgência em reconhecermos a ação de Tânatos na escuta do sujeito na clínica. Para isso, foi preciso resgatarmos as indicações contidas nos textos antropológicos de Freud no que concernem a duas principais ideias: a primeira delas seria a transmissão, ao longo da evolução humana, de uma figura paterna diversa e concomitante àquela do pai odiado da horda primeva. Em reverência a este pai, constituiu-se uma ligação entre os humanos calcada não apenas na renúncia e na culpa, mas também no que Freud (1939 [1934-1938]/2018) considerou ser um "avanço na espiritualidade", decidindo contra a percepção sensorial direta em favor da intelectualidade e do compartilhamento de lembranças, inferências e reflexões. Esta seria a segunda ideia que dá suporte aos argumentos de Zatzman (1996). 
Através dela, a autora indica a existência de uma saída psíquica frente à repetição interminável da morte originada no evento mítico do assassinato do pai. Se por um lado perdurariam a culpa e a renúncia, por outro o "espírito", o intelecto, se encarregariam de transpor intensidades pulsionais em pensamentos, linguagem compartilhável com o grupo.

Na clínica, o analista se apropriaria justamente dessa característica constituída ao longo da evolução humana: a capacidade de transpor o pulsional em experiências simbólicas compartilháveis, o que abrangeria, para Zaltzman, as figuras do pulsional mortífero. Este seria o viés transgressivo de um processo analítico, sustentando a proposta de que o sujeito deve reconhecer a desordem, a ruptura, o desligamento. Viola indicações e práticas que visam "amansar" a pulsão de morte, sob a pretensão de encadeá-la ao trabalho de Eros, da ligação, da união e da busca de harmonia, o que poderia ser tão prejudicial ao sujeito quanto o excesso de desordem.

Neste terceiro capítulo, encerramos a pesquisa seguindo o fio condutor proposto através de mais uma aposta teórica transgressiva. Desta vez, dirigimos a atenção às preocupações da autora com relação ao processo civilizatório. Evitamos utilizar aqui o termo "processo cultural" pois este será apontado justamente como o viés transgressivo da busca civilizatória. Para propor esta divergência, a estratégia utilizada por Zaltzman foi recorrer a diferentes definições presentes nos ensaios freudianos da década de 1930 (FREUD, 1930/2010, 1933a/2010) nos quais ele aborda o assunto. Isso permitiu a demarcação, no próprio texto do autor, de perspectivas que afastam os dois processos.

O que pretendemos demonstrar nesta delimitação e especificação do que seria o trabalho de cultura concerne justamente à leitura transgressiva que podemos fazer de seu funcionamento. Enquanto a perspectiva civilizatória trabalha a favor da renúncia pulsional e do recrudescimento do recalque, o trabalho de cultura, ao contrário, buscaria transpor o pulsional em saber consciente. Mais uma vez, é na contramão dos preceitos moralizantes que saídas lúcidas são demonstradas frente ao mal-estar humano. A psicanalista propõe interrogações acerca da ética imposta pelo processo civilizatório e seu caráter superegoico no psiquismo, confrontando-o ao que ela recorta, na obra de Freud, como sendo a realização do trabalho de cultura. 
Por essa via, seria possível abordar tanto no âmbito individual quanto no coletivo, de forma mais lúcida, menos comprometida com a moral civilizada, dimensões negadas do humano, como a vertente maléfica do funcionamento psíquico e das relações objetais. Historicamente compreendido como "evento cujo agente ativo é um humano e sua consequência é uma ofensa à vida, ao corpo, ao espírito de um indivíduo ou uma coletividade ou mesmo ao futuro da humanidade" (ZALTZMAN, 2007, p. 30), o mal será um operador para compreendermos as divergências entre trabalho de cultura e trabalho de civilização.

Franquear o acesso a esta dimensão do humano, conferir-lhe um lugar no universo simbólico de cada um e dos grupos, contribuiria para evitar o seu comparecimento por meio do adoecimento e de atos violentos, bárbaros, verdadeiros obstáculos ao progresso da humanidade. Não se trata de negar os limites impostos pela própria condição humana, que se caracteriza por uma divisão entre um polo pulsional e um outro da representação, do simbólico, sendo o pulsional uma fonte inesgotável de força. A questão colocada se mostrou muito mais pautada na diferença de objetivos do uso dos recursos simbólicos, admitindo que ambos possuem limites. Mas enquanto uma via pretende que a pulsão seja afastada, renunciada, redundando em retorno violento em busca de satisfação, a outra visa capturá-la, conferindo formas mais brandas de descarga ao transpor o que era pura força em descarga via representação. Seguiremos essa discussão nos apropriando mais rigorosamente do arcabouço metapsicológico no tópico subsequente.

\section{1}

\section{Trabalho de cultura versus trabalho de civilização}

Notadamente, após a publicação de seu primeiro ensaio em 1979, o termo "pulsão anarquista" deixa de ser mencionado em escritos posteriores de Zaltzman. Todavia, a ideia nele contida resta, sem dúvida, recoberta por outras proposições, das quais é possível destacar a leitura que ela estabelece para o termo "trabalho de cultura" nos ensaios freudianos. Sua articulação tem início quando a psicanalista se mostra incomodada frente ao pessimismo trazido por Freud (1930/2010) em "O mal-estar na civilização". 
Vamos considerar a abordagem dessa temática conforme consta no último livro publicado pela autora, "L'Esprit du mal" (Zaltzman, 2007). Nele, o interesse teórico gira em torno da dimensão do "mal" no humano, destacando a apreensão possível pelo viés do trabalho de cultura. Esta seria a via que comporta respostas mais lúcidas sobre a esperança possível frente à precarização do projeto de uma sociedade vivendo em conjunto e de modo harmonioso. Paradoxalmente, o caminho exige que sejam transgredidas as imposições civilizatórias que, pretensamente, levariam ao objetivo delineado.

Essencialmente, o que buscamos evidenciar no pensamento da autora em continuidade ao fio condutor de nossa pesquisa é a seguinte hipótese teórica: o salto operado pelo ganho cultural é transgressivo em relação aos interditos do pensamento e às ilusões impostas pela civilização. Esta seria a diferença que destacamos entre trabalho de cultura e de civilização. O primeiro seria transgressivo pois, frente ao mal inerente ao humano, escolheria o caminho oposto àquele tomado pela moral civilizada. Em vez de negá-lo, afastá-lo, condená-lo, o acolheria, conferindo a ele um lugar na constituição do Eu e no universo simbólico coletivo. Analisaremos mais detidamente, a seguir, essa distinção, a partir dos elementos resgatados no texto freudiano.

Nos remetendo à $31^{\text {a }}$ Conferência Introdutória, “A dissecção da personalidade psíquica", na qual Freud (1933a/2010) propõe uma definição diversa da que encontramos em seus ensaios anteriores para o termo Kulturarbeit ["trabalho de cultura"], Zaltzman (2007) acredita ter ele chegado a conclusões mais otimistas do que, por exemplo, aquela de "O mal-estar na civilização" (Freud, 1930/2010), onde estabelece a neurose e a violência como resultados do processo civilizatório. Neste último caso, o preço a se pagar pelas inúmeras conquistas possibilitadas pela convivência em grupo e pelos avanços em bens culturais seria a renúncia pulsional.

$\mathrm{Na}$ “Conferência 31" (Freud, 1933/2010), Kulturarbeit se afastaria da significação anterior e se especificaria como processo de transformação filo e ontogenética. Designaria, então, as trocas que se passam entre Id, Eu e Supereu no aparelho psíquico. Aproxima-se daquilo que ocorre durante um tratamento psicanalítico e das mudanças consecutivas à evolução da sociedade tornadas patrimônio cultural. 
Sua intenção é, realmente, fortalecer o Eu, torná-lo mais independente do Supereu, ampliar seu âmbito de percepção e melhorar sua organização, de maneira que possa apropriar-se de novas parcelas do Id. Onde era Id, há de ser Eu. É uma obra cultural como o aterro do Zuydersee, digamos (Freud, 1933/2010, p. 223).

Freud (1927/2014), em “O futuro de uma ilusão”, se recusou definitivamente a distinguir os termos Kultur - que, na língua alemã, admite significar algo interior - de Zivilisation - referido a algo externo. Segundo Fortes (2017), tal postura estaria relacionada a certa rendição de Freud frente à força da pulsão de morte. Para ele não mais importaria se a domesticação dessa pulsão se realizaria através da cultura, representada pelos métodos educativos ou através da civilização, traduzida pelo que seria o fortalecimento da política. Qualquer que fosse a via eleita, a pulsão seria determinante para que um resto permanecesse não passível de captura pelo sistema civilizatório. Não haveria, para Freud, como separar a civilização do excesso pulsional que lhe subjaz (FORTES, 2017).

Embora concordasse com o fato de que sempre haveria um resto pulsional não capturável, Zaltzman (2007) sempre se posicionou no sentido de apontar saídas possíveis para o mal-estar humano. E o que encontramos predominantemente em seus apontamentos são as saídas transgressivas. A saída vital frente ao adoecimento e a barbárie decorrentes das apostas moralizantes e repressivas da civilização seria o trabalho de cultura.

O caminho indicado foi destacar nos textos de Freud definições que permitem reagrupar os resultados de dois processos distintos, perspectiva na qual "trabalho de cultura", além de não coincidir com "trabalho de civilização", adquire um sentido bastante singular. Se, em 1930, Kultur aparece englobando componentes sociais, de educação, índices civilizatórios, na Conferência 31 (Freud, 1933/2010) se destacaria como processo de elaboração intrapsíquica e transindividual da experiência do sujeito, modificando seu desenvolvimento e a evolução do conjunto humano.

A autora compreende o trabalho de civilização de maneira mais próxima ao que Freud propõe em "Mal-estar na civilização" (1930/2010), assemelhando-o ao trabalho da história, uma vez que, como ela, retém as modificações surgidas no conjunto humano e as transmite a cada indivíduo. Os bens comuns, constituídos 
através de inúmeras renúncias individuais, caracterizariam cada civilização, cada época e seu estilo próprio, suas invenções, aquisições intelectuais, filosóficas, religiosas e científicas, entre outras. Como esses bens exercem uma influência sobre o curso da história e das civilizações, uma confusão se daria entre os produtos da civilização e o movimento da cultura.

Ao considerar haver diferença de resultados entre os dois processos, Zaltzman (2007) propõe que a ideia de civilização remete à manutenção da coesão e conservação do grupo. Se sobrepõe ao bem-estar individual e exige sacrifícios de seus cidadãos. O adoecimento que Freud (1930/2010) atribui à civilização estaria, então, justamente vinculado à idealização de funções protetoras e pacificadoras, fruto da relação transferencial estabelecida pelo sujeito com suas figuras tutelares e demais ideais de comunidade. Sociedade e civilização seriam, consequentemente, solidárias na manutenção da unidade coletiva, com ou sem satisfação dos interesses individuais, tendo o recalque como efeito e aliado.

Reserva-se, assim, à civilização ser solidária da moral, do adoecimento neurótico e da violência, uma vez que é tributária da renúncia pulsional à qual Freud (1930/2010) atribuiu valor civilizatório. A psicanálise, por sua vez, não poderia ser indiferente à distinção entre os progressos civilizatório e cultural. Isso porque, como vimos no capítulo anterior, o empenho analítico seria o de transformar elementos inconscientes singulares em língua admissível pelo grupo. A análise estaria comprometida com o trabalho de cultura, promovendo, no limite, uma reapropriação do indivíduo pela massa.

A autora estabelece que, enquanto instância de lucidez psíquica, o trabalho de cultura, do qual participa a análise, contribuiria de maneira menos ilusória à ética e à moral do que o supereu cultural. O progresso operado pelo trabalho de cultura repousaria na ampliação do conhecimento e consciência de si e do grupo. Não se trataria de sobrepor as duas ordens de conquista operadas por cada processo, cultural e civilizatório, mas especificar o progresso advindo do trabalho de cultura e sua obra de humanização.

Ao propor esta diferenciação, Zaltzman esteve preocupada em pensar sobre a questão do mal no humano. Conforme definido anteriormente, devemos apreendêlo como um evento que cause dor e sofrimento a um outro, um grupo, à humanidade 
e cujo agente é um humano. A ideia é que o processo civilizatório, ao negar a dimensão maléfica humana, não permitindo acessá-la pelas vias simbólicas, acabaria reforçando seu comparecimento em ato, por meios violentos.

Ao considerar o trabalho de análise alinhado ao trabalho de cultura, estamos dizendo que, com relação à questão da maldade humana, a cura analítica também se realiza de modo transgressivo. Acolhe as representações do sujeito que traduzem seu potencial para fazer um outro sofrer. Transgride tanto a perspectiva civilizatória quanto práticas analíticas que evitam considerar essa dimensão humana.

Mas quais aportes teóricos estariam à disposição para se pensar a maldade, a capacidade para o exercício do mal, do ponto de vista da psicanálise? Será preciso, em todo caso, recorrermos à metapsicologia. Por este caminho desvelaremos, no tópico seguinte, como a psicanálise poderia delinear a questão. De fato, a especificidade da definição de trabalho de cultura aqui apresentada só é possível ao considerarmos os conceitos metapsicológicos. A base de compreensão do trabalho de cultura é o aparelho psíquico, de modo que a acepção de cultura que abordamos está circunscrita no campo da psicanálise. Assim como o trabalho de cultura, buscaremos compreender como considerar, psicanaliticamente, o mal.

\section{2 \\ Abordagem psicanalítica do mal}

Em "Mal-estar na civilização", Freud (1930/2010) propõe que o mal, na maioria das vezes, não é algo nocivo ou perigoso para o Eu do sujeito. Ao contrário, geralmente é desejado e lhe dá prazer. Os efeitos causados no outro e a avaliação por ele feita seriam os determinantes para se considerar uma ação boa ou má. O humano se submeteria a tal avaliação por medo de perder o amor desse outro, medo advindo das suas relações primordiais onde necessitava de proteção e podia ser castigado. $\mathrm{O}$ autor não deixa dúvida de que a dimensão maléfica seria intrínseca ao próprio homem, como uma espécie de natureza maligna. Afirma que, em circunstâncias favoráveis, quando as forças psíquicas que inibem a agressividade estão ausentes, ela se expressa de modo espontâneo, revelando o ser humano "como uma besta selvagem que não poupa os de sua própria espécie” (FREUD, 1930/2010, p. 77). Ao mesmo tempo, declara a grande dificuldade dos homens em admitir seu quinhão maligno. 
Considerando essas afirmações de Freud e tendo em vista o que abordamos no tópico anterior, nos parece crucial o seguinte questionamento: "se o trabalho de cultura e a cura analítica têm objetivos semelhantes, de que forma um processo analítico deve confrontar a maldade, dado invariante da constituição psíquica?" (ZALTZMAN, 2007, p. 31-32, tradução nossa).

O termo "confrontar" é bastante emblemático da postura que temos procurado evidenciar na clínica que Zaltzman transmite. Afinal, a luta permeia seu discurso e a forma que ela encontrou para indicar a potência vital que portaria a prática psicanalítica é recorrer ao seu viés combativo. Confrontar seria trazer à baila, dar contorno, expressão, compartilhar, único meio do qual dispõe a atividade analítica. A autora considera que o processo analítico não deveria, em sua concepção, ser independente da noção de progresso moral. Logo, não seria admissível que a "natureza humana" fosse considerada um campo avesso ao analítico, o que remontaria à indignação dos primeiros discípulos freudianos ao surgimento do conceito de pulsão de morte, considerando-o exclusivamente como mortífero, enquanto Eros seria salvador.

Sendo assim, mais do que uma ideia periférica em relação ao desenrolar de uma análise, o mal deveria ser considerado um dado central do psiquismo. Ignorálo como estrangeiro ao campo psicanalítico significaria instaurar um tabu no seio da metapsicologia e das práticas de mudança da vida psíquica. Seria ignorar uma dimensão invariante da espécie humana, a qual por meio do processo analítico poderia ser nomeada, permitindo que o sujeito tome consciência de sua repetitividade.

Conforme vimos no capítulo anterior, o processo de análise, em semelhança ao trabalho de cultura, faria um duplo movimento: a passagem de um modo de pensar do Id ao seu acesso ao $\mathrm{Eu}$ e, em virtude disso, faria a transposição à linguagem comum, compartilhável, o que, por conta dessa passagem, transforma o programa psíquico da espécie. A única via de transformação geral seria a transformação individual. Nesse sentido, o "singular" possuiria um privilégio exclusivo, uma importância determinante nas transformações da condição humana.

Mas, como poderíamos pensar psicanaliticamente acerca do mal, de modo a considerá-lo um operador para a clínica? Segundo Zaltzman (2007), o mal em si, 
enquanto evento difícil de ser delimitado, não seria o que mais interessa à psicanálise. O importante numa discussão sobre ele diz respeito à sua relação com a vida psíquica, a quais instâncias poderíamos atribuí-lo. Para avançar com este questionamento, a psicanalista se apoia no pensamento de outros autores, a partir dos quais propõe suas ideias. Dentre eles, se sobressai André Green, notadamente uma de suas grandes influências teóricas.

Em "Pourquoi le mal”, Green (1988/1990) aponta que a psicanálise dedica boa parte de suas reflexões sobre o mal à sua relação com a perversão e o masoquismo originário, ligado à depressão, de modo que falar do mal é falar do sentimento inconsciente de culpabilidade. A perversão remeteria à afronta a certas instâncias repressivas, destacadamente a religião, de modo que o mal nela expresso se explicaria pela moral cristã e sua atitude condenatória com relação à sexualidade. Já o mal da depressão melancólica não encontraria nenhum tipo de explicação que elucide o fenômeno, não sendo mais os conflitos sexuais o objeto de culpabilidade, mas o próprio direito de existir do sujeito que estaria colocado à prova.

Outra forma de expressão do mal destacada por Green (1988/1990) seria a destrutividade que, diferentemente das manifestações sádicas, se apresenta por meio dos atos de assassinos sem paixão, que cometem crimes sem ao menos um contato físico com a vítima, aniquilando pela nadificação, pelo desinvestimento brutal. Esse tipo de destrutividade se associaria às figuras mais tradicionais do mal, revelando total insensibilidade à dor do outro. $\mathrm{O}$ autor revela também a existência de uma forma de amor pela maldade, tanto no modo mais banal, que seria gozar com o sofrimento do outro, quanto sua manifestação mais radical, que seria amar detectá-la, localizá-la para encontrar algo a ser exterminado. Assim, seria possível pensar que a felicidade e o bem reinariam. Esta seria uma forma de não se culpabilizar, pois o sujeito se convence de que sua ação é purificadora. "Amar o mal sem remorso funda-se na certeza de garantir o triunfo definitivo do bem" (GREEN, 1988/1990, p. 350).

Haveria, dessa forma, para Green (1988/1990), um mal definido pela interdição e o desejo de gozar sua transgressão em ato (perversão) ou fantasia (ficção). Estas seriam formas analisáveis de condutas em busca de prazer. Por outro lado, haveria uma forma de maldade caracterizada pela destruição pura e integral - 
conduta que se aproximaria do âmbito do “inanalisável”. O psicanalista egípcio conforma-se, para sustentar tal pensamento sobre as manifestações da malignidade humana, à hipótese freudiana do intrincamento e desintrincamento da pulsão de morte a Eros. Ligada à libido erótica, a pulsão de morte levaria a uma variedade de expressões. Desligada, tornar-se-ia insensata, caótica.

Zaltzman (2007) também considera que devemos entender a atitude maligna do humano como uma possibilidade de atuação das pulsões, tanto Eros quanto Tânatos, constitutivas da vida psíquica. No entanto, o mal, como um evento, não é equivalente nem substituível pela noção de pulsão de morte apenas, tampouco pela noção de pulsão sádica, de crueldade primitiva, embora as duas possam ser sua fonte.

De todo modo, para a autora o evento maligno estaria à frente. Isso porque para o funcionamento pulsional ser transformado em ato, seria preciso a participação do julgamento moral, a participação do Eu, que transforma em prazer a descarga pulsional, a perda de senso, a instauração do caos, com ou sem o comparecimento de angústia. Para sua realização, o psiquismo utilizaria todas as formas de ligação e desligamento, ou seja, todas as representações alimentadas pelas correntes pulsionais de vida e de morte.

Considerar a dimensão maléfica humana do ponto de vista do funcionamento das pulsões nos permite compreender, além de sua potencial expressividade na clínica, um aspecto que se destaca no pensamento de Green (1988/1990) bem como no de Zaltzman (2007): o fato de o mal mudar de forma, de manifestações e de suporte, mas permanecer constante ao longo da história, pois decorre do inesgotável funcionamento pulsional e sua busca por descarga. A autora atribui tal circunstância à dificuldade, ao impedimento que afeta a humanidade em considerar lucidamente essa inexorável condição do homem, dificuldade consequente do processo civilizatório. Em decorrência da incapacidade em se pensar sobre a maldade como constitutiva do humano, a consciência só a percebe como existência exterior, ao se evidenciar como ato. $\mathrm{Na}$ dimensão coletiva, isto significaria a consumação da barbárie.

Sendo assim, o conceito de pulsão nos permitiria pensar sobre a transgressividade desde o funcionamento psíquico individual até o processo 
civilizatório. Com relação a este último, enquanto predominantemente estimula a renúncia pulsional, é corrompido pelas vias do trabalho de cultura, cuja visada é transformar a pulsão, através do movimento intrapsíquico, em representantes simbólicos compartilháveis com o grupo.

É preciso que fique claro que não se trata, no pensamento de Zaltzman, de uma crença em um ideal de progresso que afrontaria inclusive o pessimismo do criador de todo o campo de saber ao qual ela se referencia. Ao contrário, o que nos parece é que a psicanalista investiga, na obra de Freud, caminhos possíveis, sem pretensão de oferecer uma panaceia para o sofrimento humano.

Isso nos remete ao incansável esforço do próprio Freud, mesmo do abismo de sua descrença no progresso humano, em abrir trilhas que levassem, minimamente, a expedientes que pudessem abrandar o desamparo humano frente à inesgotável força da pulsão. O que Zaltzman ilumina é que, mesmo as correntes pulsionais de morte e destruição podem ser aliadas do Eu e dos grupos, e nisso consistiria a transgressão em seu pensamento. A partir do tópico seguinte ficará mais claro que, longe de uma postura idealizante, a autora sugere limites intransponíveis para o trabalho de cultura ao considerar a magnitude da maldade humana, recrudescida pelo processo civilizatório ao recusá-la. No entanto, afirma a necessidade de insistirmos na luta, e esta é a beleza que enxergamos em seu pensamento.

\section{3}

\section{O mal como uma constante não evolutiva}

A maior dificuldade com a qual o trabalho de civilização se depara ao longo da história seria a de construir uma representação do mal que suceda àquela definida como atentado ao sagrado e, em particular, ao caráter sagrado da filiação. Sagrado que, conforme Freud (FREUD, 1939 [1934-1938]/2018) não teria outra origem a não ser a vontade continuada do pai original. Zaltzman (2007) recorda que é no recalque original do evento filogenético da morte do pai da horda primitiva que o mal teria sido originado, acentuando a morte como o mal original. Em seu lugar encontramos sempre a instância do interdito, do contra investimento, do recalque. Mas isso não seria suficiente para evitar sua irrupção em violência. 
Neste tópico, iremos ilustrar como o mal, embora negado, evitado, recalcado, pode ser percebido ao irromper em determinados contextos ao longo da história. A fim de demonstrar que a maldade é "um ponto umbilical, fonte do que se repete sem se fazer objeto de transformação" (ZALTZMAN, 2007, p. 69, tradução nossa) a psicanalista recorre a uma metáfora extraída da literatura. Nos remete à obra de William Golding, "O senhor das moscas" (GOLDING, 1954/2011), adaptado ao cinema em 1990 sob direção de Harry Hook. O romance explicita a multiplicidade de manifestações das excitações cruéis que podem ser observadas em todas as épocas, restando em comum o sofrimento que inflige ao outro.

Nesta trama, um educado grupo de garotos britânicos fica perdido em uma ilha, após a embarcação na qual viajavam sofrer um naufrágio. Ali, expostos a condições de vida selvagem, fora da civilização, se organizam, inicialmente, em torno da palavra e da legalidade, onde todos têm voz e participam das decisões. Mas tal organização se decompõe rapidamente frente à necessidade de agir para sobreviver. Neste contexto, uma nova organização social emerge. O grupo cria, com a cabeça de um animal e o corpo de um humano que encontra, um totem que encarna e evidencia o surgimento de forças maléficas que retratam o surgimento de regimes totalitários e seus mecanismos de morte.

O que se vê, a partir de então, é um processo de regressão civilizatória coletiva que transforma um grupo de meninos em uma massa de anônimos unidos pelo desejo e prazer de matar. Quando um deles se mostra lúcido, buscando manter o senso de justiça e as relações baseadas em regras de convivência, se torna alvo do ódio sanguinário do grupo.

Zaltzman (2007) pretende indicar, através do romance, como se dá o retorno do indivíduo à massa, à uma organização cimentada pela vontade de morte. Mostra como, em condições favoráveis, uma neoformação social se constitui, na qual o ódio se desliga do amor e da ambivalência emocional do Eu individual em relação ao outro.

Em "Psicologia das massas e análise do eu", Freud (1921/2011), aponta que, transformados em massa, os indivíduos se tornam possuidores de uma espécie de alma coletiva que os faz sentir, pensar e agir de forma bem diferente da individual. O fundamento inconsciente comum a todos é desnudado, torna-se operante e os 
indivíduos assumem características novas, que não existiam antes. A grande quantidade numérica os faria adquirir um sentimento de poder invencível, permitindo ceder às pulsões. Além disso, se tornam sugestionáveis, sendo contagiados pelas ideias. Tendem a transformar imediatamente em ato tudo o que lhes for sugerido.

No romance de Golding, um sujeito coletivo sanguinário se identifica a um pensamento assassino e a horda que surge se afasta das personalidades individuais. Passam a predominar os afetos inconscientes, a tendência à realização imediata dos desejos, regredindo a uma atividade psíquica primitiva, do mesmo modo como descreveu Freud (1912-13/2014) acerca do funcionamento da horda primeva.

Contudo, Zaltzman (2007) destaca uma diferença entre o grupo de garotos e a horda proposta por Freud: a ausência da vontade exclusiva de um pai que determine os desígnios do grupo e instaure uma lei, uma ordem. Tal horda sem pai se aproximaria do clã totêmico, no qual um totem se instaura como oposição à organização através da palavra inicialmente proposta. $\mathrm{O}$ totem representaria a substância comum, a identidade da espécie. No entanto, no caso dos garotos, haveria totem sem tabu, sem a moralidade característica dos povos primitivos (FREUD, 1912-13/2014). Com tal apontamento, indica-se que a regressão daquele grupo não engendrou o retorno a um estado anterior da evolução, mas um estado posterior, antes inexistente, do mesmo modo como ocorre com um indivíduo ao longo da vida.

A autora nos relembra que, do ponto de vista individual, durante uma análise, é impensável evocar um movimento regressivo sem o associar à fixação a uma posição libidinal em impasse. Esse ponto exerceria atração, retroativamente, sobre posições posteriores a partir de uma experiência de prazer ou dor que alimenta uma repetição. Contudo, uma regressão não seria o retorno a uma situação libidinal anterior do mesmo modo como ocorreu. Instaura, na verdade, uma neoformação, uma organização neurótica ou psicótica.

A partir dessa referência, através do romance de Golding, são apontados instrumentos para a análise da regressão coletiva em tempos de guerra, totalitarismo e fanatismo. A regressão não designaria apenas o retorno a um estado psíquico primitivo, mas, também, o que ela produz de novo. Se a conjuntura individual 
produz o adoecimento neurótico, no plano coletivo Zaltzman (2007) supõe haver uma atração imperiosa, em determinadas situações, do psíquico primitivo que invade a cena sócio-política. "Quando uma civilização se decompõe sob efeito de golpes de força, externos ou internos, pode-se dizer que retornou à barbárie" (ZALTZMAN, 2007, p. 20, tradução nossa). Se instauraria, então, uma organização social nova na qual o ódio se presentifica em ato, sem a ambivalência com o amor que caracteriza todo ser humano.

O fato dessa amálgama de crueldade se estabelecer indica a existência, no psiquismo de cada um, de uma parcela de ódio que irrompe violentamente. Zaltzman considera que a hipótese de uma progressão no psiquismo reencontra sempre a objeção de uma constante não evolutiva da condição humana, irremediável, inamovível: a dimensão do mal. Tal noção possuiria numerosos ascendentes conceituais, desde os religiosos até os jurídicos, que procuram, a partir dela, delimitar também a noção de humano. Mas como partem do ponto de vista moral e sua visada utópica, se esforçam em contrapô-lo ao que define o humano, considerando o maligno algo da ordem do inumano. No tópico seguinte veremos um exemplo histórico de como a civilização, ao pretender se "purificar", elide da concepção de humano o que intrinsecamente o constitui. Com isso, não faz mais do que perpetuar e recrudescer o mal que intenciona extirpar.

\section{4}

\section{O crime contra a humanidade e o intocável do mal}

A alegoria literária apresentada delineia precisa e sucintamente a hipótese de que a crueldade humana permanece latente, bastando condições propícias para irromper. Contudo, nossa história, marcadamente o século XX e as guerras que assolaram países, o extermínio de povos, escancararam a desmesura e o descontrole da maldade entre os humanos. Não foi sem razão que Freud (1930/2010) se mostrou absolutamente desacreditado em qualquer tendência ao progresso da civilização.

Se a pretensão humana é de que a razão e seu poder de entendimento do irracional permitisse mudanças de ordem consciente e inconsciente, Zaltzman novamente nos remete a Freud (1925/2011): o progresso intelectual, o acréscimo 
em inteligência e saber não necessariamente trazem consigo um progresso moral. Não devemos confundir esse acréscimo em inteligência, ao modo de um aprendizado, com o uso da intelectualidade para proceder com o remanejamento da pulsão através de representantes simbólicos, o que se alinha ao trabalho de cultura. No caso dos esforços civilizatórios, a imposição de regras e, sobretudo, a tentativa de forjar uma concepção idealizada de humano não dão conta de extirpar do psiquismo as correntes de forças que alimentam o exercício da crueldade e destruição.

Um exemplo histórico desta tentativa idílica apontado por Zaltzman (2007) seria o surgimento da noção de crime contra a humanidade. Esse conceito jurídico, ao mesmo tempo que designa o extremo do mal, imprescritível, revela a dificuldade que impede o progresso civilizatório em alcançá-lo. Ocorre, então, que o mal acaba por prosperar ao se fazer inacessível, se camuflando no próprio movimento do trabalho de civilização. O que a autora explicita é que, ao se formar uma nova categoria jurídica que atribui à humanidade um sentido novo, o mal se torna indefinido. A princípio, parece uma articulação confusa, mas explicaremos detalhadamente nos parágrafos seguintes como isso pode ocorrer, de modo que ao final do tópico teremos esclarecido a hipótese de como a lei, pretendendo combater o mal, o perpetua.

Comecemos por remontar ao surgimento do conceito: o crime contra a humanidade aparece pela primeira vez como noção jurídica em 1945 no Estatuto do Tribunal Militar Internacional de Nuremberg (HUHLE, 2011). Teria sido fortemente ancorado no contexto histórico de extermínio nazista. A partir de então, foram considerados crimes contra a humanidade os assassinatos, o extermínio, a redução à escravidão, a deportação e outros "atos inumanos" cometidos contra uma população civil, antes ou durante períodos de guerra. E, ainda, perseguições por motivos políticos, raciais, religiosos, ainda que não constituam violação segundo o direito interno do país onde ocorreram.

A Corte de Roma, redigida em 1998, definiu, em seu artigo $7^{\circ}$, de maneira mais genérica, os crimes contra a humanidade como todo "ato inumano" que cause, intencionalmente, grande sofrimento ou atentado grave à integridade física ou à saúde mental. 
O que se coloca como problemático tanto no Estatuto de Nuremberg quanto na Corte de Roma, no ponto de vista de Zaltzman (2007), é a designação do crime como "ato inumano". Crime e humano se definiriam reciprocamente, ao se excluírem. Logo, o criminoso, ao cometer um "ato inumano" fica excluído da condição de humano. O crime, o mal, deixaria de ser algo da ordem do humano, ficando elidido de sua concepção.

Outro episódio que Zaltzman (2007) relembra no qual a elisão do mal apareceria mais explicitamente teria sido a promulgação da lei alemã nomeada Wiedergutmachen, de 1956. Através dela ficou determinada que os danos causados aos alemães, ex-alemães e apátridos pelo nacional-socialismo seriam indenizados. A indenização substituiria a responsabilidade da política de extermínio do Terceiro Reich. A culpabilidade coletiva e individual foi encoberta por uma justiça indenizadora, que preferiu evitar o confronto com os causadores dos danos infligidos.

No Brasil, conhecemos situação similar decorrente do período de ditadura militar. Ao fim daquele regime foi criada, em 1979, a Lei de Anistia, com a finalidade de reverter as punições aos cidadãos brasileiros considerados criminosos políticos durante o regime militar. Em 2001 foi criada a Comissão da Anistia com o objetivo de reparar moral e economicamente as vítimas de atos de exceção, arbítrio e violações aos direitos humanos cometidas entre 1946 e 1988. Do mesmo modo, o Estado assumiu a responsabilidade pelos crimes cometidos, os criminosos não foram punidos e o mal por eles engendrado foi elidido da história.

A elisão do mal, de seus agentes, sua qualificação de inumano em contradição com a característica universal da humanidade seria, para Zaltzman (2007), o signo de um sintoma psíquico. Revelaria o ponto de maior fragilidade do trabalho de civilização.

A construção do conceito de crime contra a humanidade, no que revela do processo de avanço civilizatório, responderia ao que Zaltzman (2007) propõe circunscrever como trabalho de civilização no texto freudiano. Acrescentaria uma representação nova ao capital simbólico humano na tentativa de deslocar os objetivos das pulsões (FREUD, 1930/2010). Esta nova consciência de humanidade, este novo valor jurídico e moral se inscreve no capital dos ideais coletivos e poderia 
até modificar, em parte, os objetivos pulsionais, as condutas criminais. Mas, ao mesmo tempo, revela um fracasso, ao fazer desaparecer o que pretendia criar.

O que se apresentaria como ponto falho seria a extensão do termo "humanidade" sem incluir as contradições que tal construção também produz. Em vez de considerar a dimensão criminal da condição humana, a noção idealizada de humano reenviaria o mal ao limbo do inumano. Zaltzman (2007) supõe que, no trabalho civilizatório cumprido pela via da criação do conceito de "crimes contra a humanidade", a maldade se apresentaria como sujeita ao recalque.

A novidade dessa criação teria sido erigir em lei moral um estado psíquico: ninguém pode ser expulso da espécie humana. Mas a perda de inteligibilidade do mal no avanço dos ideais de humanidade permite concluir que tal avanço é sem correspondência na vida psíquica inconsciente. Ao contrário, sua resistência em se fazer analisável no campo consciente indica a sua ativa consistência inconsciente. Logo, ainda que não se trate de desaconselhar tais "manobras" civilizatórias, seria necessário também estimular vias que possibilitassem aos sujeitos contatar seu potencial maléfico e tomar consciência, no sentido propriamente psicanalítico da expressão, do mal que lhes habita.

\section{5 \\ Do evitamento ao acolhimento do mal}

O que a articulação teórica de Zaltzman (2007) revela é uma certa relação de estranheza, conforme também apontou Freud (1930/2010), entre a construção da ideia de humanidade e o reconhecimento da sua dimensão maligna. A autora nos propõe, no entanto, considerarmos como ganho cultural os avanços de um conhecimento lúcido, de uma inteligência acerca da realidade humana, independente do princípio do prazer.

Freud (1915/1987), em "Neurose de transferência: uma síntese”, define a humanização como um processo ligado à evolução da instância psíquica egoica, a aparição e desenvolvimento de tratados psicossomáticos específicos dos humanos que modificam a herança da espécie. Em "Acerca de uma visão de mundo" (FREUD, 1933/2010), propõe que tal processo desloca os objetivos pulsionais e faz 
com que os homens repugnem o que era até então suportável, aceitem determinadas restrições a seus desejos pulsionais e entendam as considerações pelo próximo dele esperadas.

Mas tal processo se daria apenas pela via do confronto com as forças que, por meios catastróficos, obrigam a avançar nas tentativas de proteção contra a barbárie, como no contexto do surgimento da definição dos crimes contra a humanidade. Zaltzman (2007) considera que esta noção abstrata e ideal de humanidade, como todo conceito, obedeceria a um duplo movimento psíquico. Há um investimento unificante por um lado e, por outro, a diferenciação, exclusão e desinvestimento daquilo que a contradiz. Reconhecemos o que se aceita como próprio ao gênero humano e afastamos o que se diferencia dele.

No texto "A negação", Freud (1925/2011) explicita como ocorre esse movimento desde os primórdios da constituição psíquica. Ele propõe que a função intelectual, através do julgamento, pronunciaria se uma propriedade está ou não contida em determinada coisa e concederia ou contestaria a uma representação a existência na realidade. Mas a operação do pensamento se separa dos movimentos afetivos, que ditam suas próprias escolhas de inclusão ou exclusão, conforme o princípio do prazer.

Zaltzman (2007) esclarece que, a partir de tal explicação, podemos compreender como se constituiu a noção de humanidade ao longo da história. Erigiu-se uma realidade ideal, uma forma de pensamento ilusório, segundo as determinações do processo secundário. Constituiu-se como uma utopia, um ideal de humanidade separado de tudo o que não é aceito para caracterizá-la, que passou, então, a ser nomeado inumano.

Mas a operação intelectual, emancipada dos movimentos de afeto, que a aceitam ou a recusam, não seria capaz de modificar os processos primários dos quais se afasta. $\mathrm{O}$ que vemos historicamente confirmado é que a ideia de uma humanidade universal, sem hierarquia, não conseguiu eliminar o ódio racial, o extermínio de grupos, a discórdia entre os povos. O estabelecimento jurídico de uma comunidade universal fraterna não foi suficiente para pacificar os conflitos sanguinários entre nações. 
Diferentemente, o trabalho de cultura repousaria sobre outro princípio de ação. Sua pretensão seria tornar inteligível o que se apresenta, em cada sujeito e nos grupos, como opaco. Esse é o movimento que produz a mudança do sujeito, oferecendo vias de descarga alternativas à irrupção violenta. Esta seria a trama do trabalho de cultura, ao qual a psicanálise estaria alinhada.

Nesse sentido, o avanço no processo de cultura não exige tão somente um ganho em conhecimento. Logo, a humanização não poderia ser pensada apenas como um acréscimo quantitativo, como se o homem se tornasse cada vez mais humano à medida que evolui seu processo de conhecimento sobre si. Seu futuro dependeria de uma percepção dos determinantes inconscientes que, elucidados, passariam a lhe constituir e a operar sobre ele.

Por esse motivo, a única via possível para concebermos qualquer transformação no âmbito geral, coletivo, seria a transformação individual. É assim que Zaltzman (2007) considera o privilégio exclusivo do individual e sua importância determinante nas transformações da condição humana.

\section{6 \\ Possibilidades e limites do trabalho de cultura}

Embora estejamos tratando de uma concepção bastante específica de trabalho de cultura partindo dos argumentos da psicanálise, não se trata de reduzir o conceito à prática analítica. Existem outros meios culturais - esses podem ser pensados de modo mais genérico, como capacidades adquiridas pelo homem como membro da sociedade - que também assumem o papel mais restrito do trabalho de cultura na forma como temos pensado. A arte, mormente a literatura, seria capaz de funcionar no processamento de mudanças subjetivas, facilitando o acesso a instâncias socialmente recusadas de nossa vida psíquica.

Já nos momentos finais de "L’esprit du mal”, Zaltzman (2007) propõe percebermos, por esta via, a contribuição positiva do mal, sua função de inspiração para o trabalho de cultura. A via artística permitiria apreendermos o poder de atração do mal de um modo que jamais a literatura edificante conseguiria alcançar. "Bons sentimentos produzem literatura ruim" (p. 91). Basta lembrarmos, por 
exemplo, de autores clássicos como Dostoiévski e o eterno impacto que suas obras, seus personagens maus, exercem sobre humanidade.

Freud (1908 [1907]) já declarava haver mecanismos de suspensão da censura e identificação do leitor/espectador aos comportamentos maléficos e ao sentimento de impunidade dos personagens maus, que muitas vezes ocupam o lugar de júbilo identificatório. Dessa maneira, permitiria a realização de desejos secretos, via pela qual seria possível estabelecer um ganho de inteligência acerca do mal.

Outro caminho seria a narração da experiência direta do mal, o reencontro com sua crueza e materialidade, como procedem os autores que relatam suas experiências de vida enquanto aprisionados nos campos de concentração. Antelme (1957/2013), um dos sobreviventes do holocausto, pode descrever e nos fazer refletir acerca da maldade humana, chegando a estabelecer para ela um limite: o poder de matar. O carrasco, nos diz ele, "pode matar um homem, mas não pode transformá-lo em outra coisa" (ANTELME, 1957, p. 252). O humano jamais deixará de sê-lo, a despeito de todo mal feito a ele. Ao mesmo tempo que reconhecemos o extremo da crueldade humana, nos é apontada a sua capacidade em resistir, em um vínculo último à vida.

Tanto na forma de ficção como no relato testemunhal, essas obras nos permitem acessar os piores e mais cruéis impulsos humanos. São meios admissíveis de reconhecimento e elaboração da maldade sem que seja necessário a cada um repetir a experiência para dela abdicar.

Porém, conforme já aludimos algumas vezes, quaisquer propostas de elaboração do pulsional que venhamos a conhecer não serão suficientes para esgotar o seu excesso. Acompanhando a lucidez de Freud (1930/2010, 1932/2010), Zaltzman (2007) considera que, quanto ao mal, uma parte restará sempre intratável, resistente, estrangeira aos meios de elaboração possíveis pelo trabalho de cultura. Reafirma-se a hipótese de um núcleo não transformável que seria a última possibilidade de se pensar sobre ele, o limite de sua representação.

Mitigar a experiência maléfica humana transgredindo as vias civilizatórias, dando forma e lugar ao que geralmente é recusado, comporta limites e remete ao inexorável desamparo da condição humana frente ao pulsional contra o qual os recursos da linguagem são insuficientes para esgotar. 
Justamente na tentativa de se proteger contra o desamparo é que o humano, muitas vezes, cede à barbárie. O trabalho de cultura, a tomada de consciência, se tornaria impotente frente às novas realidades que os grupos são capazes de reavivar.

Essa constante ameaça de irrupção da barbárie explica a necessidade que as nações têm de manter viva a memória das tragédias pelas quais passaram. É como se buscassem, pelo viés da cultura, aquilo que, pela insistência civilizatória propõem por meio de medidas como a criação da instituição "crimes contra a humanidade". Se, por um lado, excluem da concepção de humano a capacidade de cometer atrocidades, por outro expõem o que há de mais horrendo em sua natureza. Assim se concebeu, por exemplo, o Memorial do holocausto, em Berlim, o Museu da memória e dos direitos humanos, em Santiago do Chile e o Memorial da Resistência, em São Paulo, para citar os que melhor conhecemos.

Estas seriam vias que, ao nosso ver, reverberam a última reflexão de Zaltzman (2007) antes de sua morte em 2009, demonstrando sua inabalável firmeza e aposta nos caminhos que a psicanálise pode pretender frente à inelutável força da pulsão. "L’esprit du mal" se encerra com uma afirmação carregada de vigor e alguma esperança, com a qual também gostaríamos de concluir este último capítulo de nossas reflexões:

O trabalho de cultura não deveria se limitar a operar em cada sujeito de forma individual. Necessita, outrossim, que a humanidade, que se purifica de seus próprios crimes se sacralizando, suceda a conhecer intimamente nela, a dimensão do mal (p. 109, tradução nossa). 


\section{5 \\ Considerações finais}

Ao concluirmos esta pesquisa sobre a obra de Zaltzman, foi possível confirmarmos a hipótese que compareceu desde as primeiras leituras de seus ensaios: a transgressão, além de ser uma característica marcante de seu pensamento, é considerada uma saída psíquica vital para o ser humano. Cumpre um objetivo específico nos mais variados fenômenos da vida psíquica individual e coletiva: assegurar saídas quando forças externas reprimem, submetem ou ameaçam a vida de um indivíduo ou um grupo.

Em um primeiro momento, a pesquisa elucidou a dimensão transgressiva do funcionamento da pulsão de morte, principal temática de seus escritos. Desde "A pulsão anarquista" (Zaltzman, 1979/1994), obra princeps da autora, foi o funcionamento transgressivo, de luta pela vida e não de agenciamento da morte, atribuído àquela força, que se revelou. Através do trabalho de desligamento garantiria a sobrevivência, ao se rebelar contra as próprias forças da pulsão de morte que destinariam o sujeito ao fenecimento.

Numa leitura estrita, Freud (1920/ 2010, 1930/2010), ao introduzir a noção de pulsão de morte, a apresentou como um impulso individualista, virtualmente agressivo, destruidor, cujos desligamentos conduziriam o sujeito, no limite, à morte física e psíquica. Zaltzman (1979/1994) além de considerar um viés criador, renovador da vida, desta pulsão, propôs para ela uma dimensão anárquica. Esta se apresentaria em situações-limite e/ou adversas, nas quais a força de desligamento sustentaria a manutenção do sujeito em vida ao se voltar contra as próprias forças de desligamento, impedindo seu avanço que fatalmente levaria o sujeito a sucumbir. Desse modo, alertou sobre o possível reducionismo em atribuir uma positividade e negatividade unilaterais à pulsão de vida e de morte, respectivamente.

No que tange à clínica, o aspecto transgressivo comparece ao propor que as manifestações da pulsão de morte devem ocupar um lugar nas representações conscientes do sujeito. A própria ideia de representação, tradicionalmente remetida à ligação, é violada. A pulsão de morte, em seu modo de funcionamento, via 
desligamentos, rupturas, se faria representar. Escutar seus apelos seria a alternativa possível frente à irrupção violenta em ato ou pelas vias deformadas de adoecimento. Neste sentido, a cura psicanalítica se proporia a franquear possibilidades de expressão e reconhecimento de todas as forças que operam no psiquismo, e não apenas da pulsão sexual, sustentando um trabalho de liberação pulsional por meio da palavra.

Como última transgressão que destacamos na obra de Zaltzman, apresentamos sua leitura do trabalho de cultura na obra freudiana. Este seria transgressivo pois, frente ao mal inerente ao humano, escolheria o caminho oposto àquele tomado pelo processo civilizatório. Em vez de, como este, negá-lo e afastálo, o acolheria, conferindo ao mal um lugar consciente no Eu, permitindo ser compartilhado no universo simbólico coletivo.

Demarcar a diferença entre os dois processos cumpriria o objetivo de franquear o acesso à dimensão da maldade como condição humana. Isso seria necessário porque Zaltzman (2007) defende que a dificuldade em se pensar sobre o mal é prevalente, justamente por seu vigor e tendência afrontosa a qualquer forma de submissão às vias repressivas.

Seguindo também um caminho de violação das imposições autoritárias, sobretudo pelo moralismo dominante em uma sociedade, o trabalho de cultura pretenderia acomodar representações excluídas da dimensão humana, das quais o "mal" seria uma das mais alijadas do conceito de humanidade, sempre respondendo aos ideais historicamente concebidos.

Ao encerrar sua última obra, Zaltzman (2007) propõe, mediante o trabalho de cultura, o esforço de admissão, por parte da humanidade como um todo e não apenas individualmente, desta dimensão maléfica, concomitantemente íntima e estranha às fronteiras egoicas de cada indivíduo. Mais do que uma ideia periférica em relação ao desenrolar de uma análise, o mal deveria ser considerado um dado central do psiquismo. Ignorá-lo como estrangeiro ao campo psicanalítico significaria instaurar um enclave de pensamento-tabu no seio da metapsicologia das práticas de mudança da vida psíquica, ignorando uma dimensão invariante da espécie. Somente 
identificando-a seria possível nomeá-la e trazer à consciência sua mórbida repetitividade.

Portanto, a obra de Zaltzman testemunha a aposta na lucidez como via de progresso da humanidade, o que só poderia ser conquistado por meio de transgressões e desvios dos recalques, violências e limites impostos pela civilização.

Concluir esta pesquisa revelando como os diversos conceitos abordados podem ser pensados na perspectiva da transgressão se impôs a nós como importante e imprescindível operador de trabalho. Na avaliação de sua obra, fica evidente o quanto a autora foi afetada por uma história de proximidade com a violência e a morte, de modo que transgressor (a) é seu pensamento, sua existência, sua clínica. De certa maneira, ela buscou de forma lúcida e realista, caminhos para enfrentar as forças de morte e de destruição. Um empreendimento que se mostra de valor inestimável aos esforços e desafios impostos pelos panoramas clínico e teórico da psicanálise contemporânea. Justamente na abordagem transgressiva de Nathalie Zaltzman reside sua maior contribuição não apenas ao campo analítico, mas, também, à cultura humana - sempre mutante, imprevisível e insubmissa aos preceitos civilizatórios. 


\section{Referências Bibliográficas}

ANDRÉ, J. La vie sans filet. In Psyché anarchiste - Débattre avec Nathalie

Zaltzman. Paris: Presses Universitaires de France, 2011.

S. ASSOUN, P.L. (1976). Freud, a Filosofia e os Filósofos. Rio de Janeiro: Francisco Alves, 1978.

BEETSCHEN, A. Le défi de la déliaison. In Psyché anarchiste - Débattre avec Nathalie Zaltzman. Paris: Presses Universitaires de France, 2011.

BIRMAN, J. As pulsões e seus destinos. Do corporal ao psíquico. Rio de Janeiro: Editora Civilização Brasileira, 2009.

CABRAL, P.E.P.L. \& PALUMBO, J.H.P. (2016). A Pulsão Anarquista e a Resistência Diante da Morte e da Massificação. In Revista Subjetividades, Fortaleza, 16(3): 84-96, dez. 2016. Disponível em: <http://periodicos. unifor.br/rmes /article /view/5166/pdf>. Acesso em 08 jul. 2018.

DAVID-MENARD, Monique. Como ler Além do princípio do prazer? In: Reverso, Belo Horizonte, v. 37, n. 69, p. 99-112, jun. 2015. Disponível em $<$ http://pepsic.bv salud.org/scielo.php?script=sci_arttext\&pid=S010273952015000100011 \&lng =pt\& nrm=iso>. Acesso em 05 jun. 2018.

EHRENBERG, C. Les pulsions de mort, auxiliaires de vie. In Psyché anarchiste - Débattre avec Nathalie Zaltzman. Paris: Presses Universitaires de France, 2011.

FERENCZI, S. (1922). A Metapsicologia de Freud. In: Obras Completas Volume IV. São Paulo: Martins Fontes, 2011.

FORTES, I. A dor psíquica. Rio de Janeiro: Cia de Freud, 2012.

Barbárie versus civilização: A problemática da Bildung. In: Psicol. Soc., Belo Horizonte, v. 29, p. 01-07, 2017. Disponível em: <http://www.scielo. br/scielo. php?script=sci_arttext\&pid=S0102-7182201 $7000100213 \& \operatorname{lng}=$ en \& nrm=iso>. Acesso em 04 ago. 2018.

FREUD, S. (1895) Projeto para uma psicologia científica. In: Edição standard das obras psicológicas completas de Sigmund Freud, v. 1. Rio de Janeiro: Imago, 1969.

(1900) A interpretação dos sonhos. In: Edição standard das obras

psicológicas completas de Sigmund Freud, v. 5. Rio de Janeiro: Imago, 1969.

(1905) Três ensaios sobre a teoria da sexualidade. In: Sigmund Freud, obras completas, v. 06. São Paulo: Cia das Letras, 2016. 
(1908) A moral sexual "cultural" e o nervosismo moderno. In: Sigmund Freud, obras completas, v. 08. São Paulo: Cia das Letras, 2015.

(1912-13) Totem e tabu. In: Sigmund Freud, obras completas, v. 11. São Paulo: Cia das Letras, 2012.

(1914) Introdução ao narcisismo. In: Sigmund Freud, obras completas, v. 12. São Paulo: Cia das Letras, 2010.

(1915a) Considerações atuais sobre a guerra e a morte. In: Sigmund Freud, obras completas, v. 12. São Paulo: Cia das Letras, 2010.

(1915b) Neuroses de transferência: uma síntese (manuscrito recém descoberto). Rio de Janeiro: Imago, 1987.

(1915c) A repressão. In: Sigmund Freud, obras completas, v. 12. São Paulo: Cia das Letras, 2010.

(1915d) Os instintos e seus destinos. In: Sigmund Freud, obras completas, v. 12. São Paulo: Cia das Letras, 2010.

(1917) A angústia. Conferências introdutórias à psicanálise. Conferência 25. In: Sigmund Freud, obras completas, v. 13. São Paulo: Cia das Letras, 2014.

(1920) Além do princípio do prazer. In: Sigmund Freud, obras completas, v. 13. São Paulo: Cia das Letras, 2010.

(1921) Psicologia das massas e análise do eu. In: Sigmund Freud, obras completas, v. 15. São Paulo: Cia das Letras, 2011.

(1923) O Eu e o Id. In: Sigmund Freud, obras completas, v. 16. São Paulo: Cia das Letras, 2011.

(1924a) A dissolução do Complexo de Édipo. In: Sigmund Freud, obras completas, v. 16. São Paulo: Cia das Letras, 2011.

(1924b) O problema econômico do masoquismo. In: Sigmund Freud, obras completas, v. 16. São Paulo: Cia das Letras, 2011.

(1925) A negação. In: Sigmund Freud, obras completas, v. 16. São Paulo: Cia das Letras, 2010.

(1930) O mal-estar na civilização. In: Sigmund Freud, obras completas, v. 18. São Paulo: Cia das Letras, 2010.

(1931) Manuscrito inédito de 1931. São Paulo: Blucher, 2017. 
(1933a) A dissecção da personalidade psíquica. Novas conferências introdutórias à psicanálise. Conferência 31. In: Sigmund Freud, obras completas, v. 18. São Paulo: Cia das Letras, 2010.

(1933b) Angústia e instintos. Novas conferências introdutórias à psicanálise. Conferência 32. In: Sigmund Freud, obras completas, v. 18. São Paulo: Cia das Letras, 2010.

(1937a) Análise terminável e interminável. In: Sigmund Freud, obras completas, v. 19. São Paulo: Cia das Letras, 2018.

(1937b) Construções em análise. In: Sigmund Freud, obras completas, v. 19. São Paulo: Cia das Letras, 2018.

(1939 [1934-1938]) Moisés e o monoteísmo. Sigmund Freud, obras completas, v. 19. São Paulo: Cia das Letras, 2018.

(1940 [1938]a) Compêndio de Psicanálise. In: Sigmund Freud, obras completas, v. 19. São Paulo: Cia das Letras, 2018.

(1940 [1938]b) A cisão do Eu no processo de defesa. In: Sigmund Freud, obras completas, v. 19. São Paulo: Cia das Letras, 2018.

GARCIA-ROSA, L. A. Acaso e repetição em psicanálise. Rio de Janeiro: Jorge Zahar Editor, 1986.

GOLDING, W. (1954) O senhor das moscas. São Paulo: Nova Fronteira, 2011.

GREEN, A. (1988). Por que o mal? In: A loucura privada: psicanálise de casoslimites. São Paulo: Escuta, 2017.

(2010) ¿Por qué las pulsiones de destrucción y muerte?. Buenos Aires: Amorrortu, 2014.

Les cas limite. De la folie privée aux pulsions de destruction et de mort. Revue française de psychanalyse 2011/2 (Vol. 75), p. 375-390.

GUARNIERI, R. Nathalie Zaltzman: une pensée anarchiste à l'epreuve de l'histoire. In Psyché anarchiste - Débattre avec Nathalie Zaltzman. Paris: Presses Universitaires de France, 2011.

HYPPOLITE, J. (1954) Comentário falado sobre a Verneinung de Freud. In: Escritos. Rio de Janeiro : Jorge Zahar Editor, 1998.

HOUAISS, A. Dicionário Houaiss da Língua Portuguesa. Rio de Janeiro: Ed. Objetiva, 2001.

HUHLE, R. Hacia una comprensión de los "crímenes contra la humanidad" a partir de Nuremberg. In: Estud. Socio-Juríd, Bogotá, v. 13, n. 2, p. 43-76. 
Disponível em: <http://www.scielo.org.co/scielo. php? script=sci_arttext\& pid =S0124-05792011000200003\&lng=en\&nrm=iso >. Acesso em 10 set. 2018.

KLIER, N. A violência do sexual e o impacto da pulsão de morte. Dissertação de Mestrado. UFRJ, 2012. Disponível em: <https://pt.scribd.com /document/ 376557277/A-Violencia-Do-Sexual-e-o-Impacto-Da-Pulsao-de-Morte> Acesso em 17 out. 2018.

LACAN, J. (1955-56) Do significante e do significado. In: O seminário livro 3. As psicoses. Rio de Janeiro : Jorge Zahar Editor, 1988.

(1960) A pulsão de morte. In: O seminário livro 7. A ética da psicanálise. Rio de Janeiro : Jorge Zahar Editor, 1997.

(1966) A direção do tratamento e os princípios de seu poder. In:

Escritos. Rio de Janeiro : Jorge Zahar Editor, 1998.

LARSSON, S. A menina que brincava com fogo. In: Millenium (Trilogia). São Paulo: Cia das Letras, 2007.

MALAURIE, J. (1955) Les derniers rois de Thulé. Paris : Terre Humaine, 1996.

OLIVEIRA, M.; WINOGRAD, M.; FORTES, I. A pulsão de morte contra a pulsão de morte: a negatividade necessária. In: Psicologia clínica. Rio de Janeiro, v. 28, n. 2, p. 69-88, 2016. Disponível em: <http:// http://pepsic.bvsalud.org /scielo.php?script =sci_abstract\&pid=S0103-56652016000200005>. Acesso em 06 nov. 2017.

PONTALIS, J.B. (1988). Não, duas vezes não. In: Da fantasia de recuperação do objeto perdido. Rio de Janeiro: Jorge Zahar Editor, 1991.

ROSENFIELD, D. L. Do mal. Para introduzir em filosofia o conceito de mal. São Paulo: LePM Editores, 1988.

SALZTRAGER, Ricardo. A memória entre intensidade e representação. Tempo psicanalítico. Rio de Janeiro, v. 46, n. 2, p. 365-380, dez. 2014. Disponível em: $<$ http://pepsic.bvsalud.org/scielo. php?script =sci_arttext\& pid=S0101$48382014000200012 \& \operatorname{lng}=$ pt\&nrm=iso>. Acesso em 01 nov. 2017.

SCARFONE, D. Besoin, emprise, 'regression' et anarchie. In Psyché anarchiste - Débattre avec Nathalie Zaltzman. Paris: Presses Universitaires de France, 2011.

TYSEBAERT, E. Tremper sa plume dans la vie. In Psyché anarchiste Débattre avec Nathalie Zaltzman. Paris: Presses Universitaires de France, 2011.

VILLA, F. (2011) A psicanálise tem meios para refletir sobre o mal?: Estudo feito em torno do livro "O espírito do mal", de Nathalie Zaltzman. In: Reverso. Belo Horizonte, v. 33, n. 61, p. 47-57, jun. 2011. Disponível em: <http://pepsic. 
bvsalud. org/scielo .php?script =sci_arttext\&pid=S0102-739520110001000 06 $\& \operatorname{lng}=$ pt\&nrm=iso > . Acesso em 08 ago. 2017.

WINOGRAD, M. Freud e a fábrica da alma : sobre a relação corpopsiquismo em psicanálise. Curitiba : Editora Appris, 2013.

ZALTZMAN, N. (1979) A pulsão Anarquista. São Paulo: Escuta, 1994.

(1986) Baiser la mort ? In: De la guérison psychanalytique, Paris, Collection Epîtres, PUF, 1999.

(1988) Une volonté de mort. In: Revue Topique 100, textes essentiels, 85-102, 2008.

Le normal, la maladie et l'universel humain. In : Revue Française de Psychanalyse vol. 60-4, L'épreuve du changement, 1123-1135. Paris : PUF, 1996. PUF, 1999.

La dictature de la guerison. In: De la guérison psychanalytique, Paris:

L'Esprit du mal. Paris: Éditions de l'Olivier, 2007. 